\title{
Bibliography of works consulted
}

Accademia di Firenze (1984) = L’Accademia di Belle Arti di Firenze: 1784-1984. Florence: Accademia di Belli Arti di Firenze.

Adams, W.J. (2006) The Red Dragoon: With the 7th Dragoon Guards in the Cape of Good Hope against the Boers and the kaffir tribes during 'The War of the Axe' 1843-48. www.leonaur.com

Agar-Hamilton, John Augustus I. (1928) The native policy of the Voortrekkers: An essay in the history of the interior of South Africa - 1836-1858. Cape Town: Maskew Miller.

'Agter die skerms by die Voortrekkermonument', Voorslag November/December: 4-5 (author unknown).

Alcock, Peter G. (2014) 'The hills above Pietermaritzburg: An appreciation', May, https://www.hiltonvillage.co.za/ images/The_Hills_Above_Pietermaritzburg.pdf and https://www.duct.org.za/education/23-hills-above-pietermaritzburg.html.

Alfred, Luke (2015) 'No easy road between Voortrekker Monument and Freedom Park', Mail and Guardian 24 April 2015, https://mg.co.za/article/2015-04-23-no-easy-road-between-voortrekker-monument-and-freedom .

Almeida de Eça, Filipe Gastão (1950) Gamitto, 1806-1866: Noticias biográficas acerca do grande explorador com subsídios ineditos para a história de Moçambique. Lisabon: Severe-Freitas-Méga.

Amptelike gids (1955) = Die Voortrekkermonument: Amptelike gids (1955). Pretoria: Die Beheerraad van die Voortrekkermonument (further editions 1957, 1959, 1960, 1963, 1969, 1972, 1976).

Amptlelike program en gedenkboek van die fees inwyding van die Voortrekkermonument 13 to 16 Desember 1949 (1949). Uitgegee deur die Voortekkermonument-inwydingskomitee.

Anderson, Benedict (1991) Imagined communities: Reflections on the origin and spread of nationalism. London: Verso.

Anderson, Gavin (2014) Heritage survey of the proposed Injisuthi Bridge upgrade, Kwazulu-Natal. http://sahra.org. $\mathrm{za} /$ sahris/sites/default/files/heritagereports/Little\%20Tugela\%20River\%20Bridge\%20Heritage\%20Report. pdf

Anderson, Michael J. (1997) The fall of Troy in early Greek poetry and art. Oxford: Oxford University Press.

Andrews, T.E. (1999) Ten walking tours through Pretoria's historical past. Pretoria.

Anguissola, Anna (2012) 'Difficillima imitatio': Immagine e lessico delle copie tra Grecia e Roma. Rome: 'L’Erma' di Bretschneider.

Anna, Paolo de (2013) Novecento di bronzo: Segreti rivelazioni dalle statue dei Vignali. Florence: Paolo de Anna.

Antonites, Annie R. and Johan Nel (2019) 'The Voortrekker Monument as memory institution: Mediating collective memory, tourism and educational programming for a local and global audience', in Handbook of research on advocacy, promotion, and public programming for memory institutions, ed. Patrick Ngulube. Hershey, PA: IGI Global, 348-365.

Arnold, Beate C., Katharina Groth and Björn Herrmann, eds (2014) Mythos und Moderne: 125 Jahre Künstlerkolonie Worpswede, exhibition catalogue. Cologne: Wienand.

Aurenhammer, Hans and Regine Prange, eds (2016) Das Problem der Form: Interferenzen zwischen moderner Kunst und Kunstwissenschaft. Berlin: Gebr. Mann.

Autry, Kimberley Robyn (2012) 'The monumental reconstruction of memory in South Africa: The Voortrekker Monument', Theory, Culture \& Society 29.6: 146-164.

Backhouse, James (1844) A narrative of a visit to the Mauritius and South Africa. London: Hamilton, Adams and Co., and New York: John L. Linney.

Bailey, Alana (2002) Die gelofte van 16 December 1838: Die herdenking en betekenis daarvan, 1838 tot 1910. MA thesis, University of Pretoria. http://repository.up.ac.za/bitstream/handle/2263/26588/Complete. pdf? sequence $=11$ \&isAllowed $=y$

Ballard, Charles (1989) 'Traders, trekkers and colonists', in Duminy and Guest (1989), 116-145.

Barlow, Leslie and R.J. Smith (1981) The uniforms of the British Yeomanry Force 1794-1914, no. 3: The Yorkshire Hussars. Tunbridge Wells: Robert Ogilby Trust.

Barnard, B.J. (1948) "n Lewensbeskrywing van Majoor Henry Douglas Warden [with a portrait, a map and a bibliography]', in Argief-jaarboek vir Suid-Afrikaanse geskiedenis, vol. 11. Cape Town: Government Printer.

Barthes, Roland (1986) The rustle of language, trans. Richard Howard. Berkeley and Los Angeles: University of California Press.

Basson, M. (1935) Voortrekker-Museum Pietermaritzburg. Pietermaritzburg: The Natal Press.

Basson, M. (1938) Voortrekker-Museum Pietermaritzburg: 1840 - Geloftekerk/Church of the Vow. 1912 - Voortrekker Museum, centenary ed. Pietermaritzburg: The Natal Press.

Beard, Mary and John Henderson (1995) Classics: A very short introduction. Oxford: Oxford University Press.

Becker, Peter (1979) Rule of fear: The life and times of Dingane, king of the Zulus. Harmondsworth: Penguin (first published by Longmans, Green and Co., 1964). 
Beer, André de (1969) Die lewe en werk van die skilder W.H.Coetzer en sy kultuurhistoriese betekenis. MA thesis, University of Pretoria. http://upetd.up.ac.za/thesis/available/etd-12072011-110708/

Beer, Manuela, Moritz Woelk and Jane Michael (2014) The Magi: Legend, art and cult, catalogue published for exhibition at the Museum Schnütgen, Cologne, 25 October 2014-25 January 2015. Munich: Hirmer.

Bellesi, Sandro, ed. (2016) Accademia di belle arti di Firenze: Scultura, 1784-1915. Pisa: Pisa University Press.

Beningfield, Jennifer (2006) The frightened land: Land, landscape and politics in South Africa in the twentieth century. London and New York: Routledge.

Ben Yosef, Ute (1989) The graven image: The life and work of Moses Kottler. Cape Town: Perskor.

Berlage, Hendrik P. (1895) Gedenkboek uitgegeven ter gelegenheid der feestelijke opening van den Delagoabaaispoorweg 1895. Amsterdam: Nederlandsche Zuid-Afrikaansche Spoorwegmaatschappy

Berman, Esmé (1983) Art and artists of South Africa. Cape Town: A.A. Balkema.

Berning, Gillian (1996) 'Indaba yamakhos’ ayibanjelwa mlando', in Zulu treasures: Of kings \& commoners: A celebration of the material culture of Zulu people (Amagugu kaZulu: Amakhosi Nabantukazana: umgubho wezinto ezihambisana namasiko amaZulu), Ulundi, KwaZulu Cultural Museum. Durban: Local History Museums (2nd ed. 2011), 43-72.

Berresford, Sandra (2007) Carrara e il mercato della scultura. Milan: Federico Motta Editore.

Berresford, Sandra, Luigi Biagini and Tamara Felicitas Hufschmidt (2009) 'Sognando il marmo': Cultura e commercio del marmo tra Carrara, Gran Bretagna e Impero (1820-1920 circa). Ospedaletto, Pisa: Pacini.

Bilbey, Diane and Marjorie Trusted (2010) “"The question of casts”: Collecting and later reassessment of the cast collections at South Kensington', in Plaster casts: Making, collecting and displaying from classical antiquity to the present, eds Rune Frederiksen and Eckart Marchand. Berlin and New York: De Gruyter, 465-483.

Bird, Annals 1 (1888) = Bird, John, The annals of Natal: 1495 to 1845, vol. I (1888). Pietermaritzburg: P. Davis \& Sons (facsimile reprint. Cape Town: C. Struik, 1965).

Bird, Annals 2 (1888) = Bird, John, The annals of Natal: 1495 to 1845, vol. II (1888). Pietermaritzburg: P. Davis \& Sons (facsimile reprint. Cape Town: C. Struik, 1965).

Blommaert, Willem (1923) 'Die Retief-Dingaan-ooreenkoms', Die Huisgenoot (September): 205-210.

Bloomberg, Charles (1989) Christian-nationalism and the rise of the Afrikaner Broederbond in South Africa, 1918-48, ed. Saul Dubow. Bloomington and Indianapolis: Indiana University Press (1st ed. 1985, Houndsmith and London: Macmillan).

Bond, J.J. (1949) The saga of the Great Trek and pictorial record of inauguration celebrations at the Voortrekker Monument. Johannesburg: The Star.

Bonner, Philip (1978) 'Factions and fissions: Transvaal/Swazi politics in the mid-nineteenth century', The Journal of African History 19.2: 219-238.

Bonner, Philip (1982) Kings, commoners and concessionaires: The evolution and dissolution of the nineteenthcentury Swazi state. Cambridge: Cambridge University Press.

Borbein, Adolf H. (1989) 'Tendenzen der Stilgeschichte der bildenden Kunst und politisch-soziale Entwicklungen zwischen Kleisthenes und Perikles', in Demokratie und Architektur: Der hippodamische Städtebau und die Entstehung der Demokratie, eds Wolfgang Schuller, Wolfram Höpfner and Ernst L. Schwandner. Munich: Deutscher Kunstverlag, 91-108.

Bosman, Martjie (1990) 'Die mitlologisering van die Groot Trek: Die rol van “Die Huisgenoot”, 1916-1938', in Onder andere: Die Afrikaanse letterkunde en kulturelle kontekste 4, eds C. Malan and G.A. Jooste. Cape Town: HSRC Press, 99-106.

Botha, Hendrik C. (1982) 'Die rol van Christoffel J. Brand in Suid-Afrika, 1820-1854', in Archives year book of South African history, 40. Pretoria: Die Staatsdrukker (first published 1900).

Botha, M.C. (1952) Die Huldejaar 1949: 'n Algemene oorsig oor die huldeuitinge van 'n dankbare volk in 1949, die jaar waarin sy gedagtegang aangetrek is deur en met behulp van die rapportryers voortgedra is na die Voortrekkermonument, Pretoria. Pretoria: Beheerraad van die Voortrekkermonument.

Botha, M.C. (1985) 'Monumente en nasionalisme', Suid-Afrikaanse Tydskrif vir Kultuurgeskiedenis 2: 31-35.

Bourdieu, Pierre (1990) 'Structures, habitus, practices', in P. Bourdieu, The logic of practice. Stanford, CA: Stanford University Press, 52-79.

Bourriot, Félix (1995) Kalos kagathos, kalokagathia: d'un terme de propagande de sophistes à une notion sociale et philosophique: étude d'histoire athénienne. Hildesheim: Olms.

Boyce, William B. (1839) Notes on South African affairs. London: J. Mason.

Boyens, José (2013) Oscar Jespers: Beeldhouwer en tekenaar, 1887-1970. Wormerveer: Stichting Uitgeverij NoordHolland.

Brah, Avtar and Annie Coombes, eds (2000) Hybridity and its discontents: Politics, science, culture. London and New York: Routledge.

Braid, Mary (1997) 'Despatches: Blacks chip away at monuments to Afrikaner power’, Independent 23 September, www.independent.co.uk/news/despatches-blacks-chip-away-at-monuments-to-afrikaner-power-1240902. html. 
Breddo, Gastone (1984) L'Accademia di belle arti di Firenze, 1784-1984. Florence: Accademia di Belle Arti.

Breytenbach, Johan H. (c. 1958) Suid-Afrikanse argiefstukke - South African archival records. Natal, 1. Notule van die Natalse Volksraad (1838-1845). Parow: Cape Times.

Brink, Elsabe (1990) 'Man-made women: Gender, class and the ideology of the volksmoeder', in Women and gender in southern Africa to 1945, ed. Cherryl Walker. Cape Town: David Philip, 273-292.

Brink, Elsabe (2011) 'The “volksmoeder”: A figurine as figurehead', in Grundlingh and Huigen (2011), unpaginated. http://rozenbergquarterly.com/reshaping-remembrance-the-volksmoeder-a-figurine-as-figurehead/

Brink, Linda (2010) Biografie van die taalstryder F.V. Engelenburg tot met die stigting van die S.A. Akademie in 1909. MA thesis, North-West University. http://dspace.nwu.ac.za/handle/10394/6488

Brinkmann, Vinzenz, Renée Dreyfus and Ulrike Koch-Brinkmann, eds (2017) Gods in color: Polychromy in the ancient world. San Francisco: Fine Arts Museums of San Francisco, Legion of Honor, and Munich and New York: DelMonico Books and Prestel.

Brooke Simons, Phillida (1995) Old Mutual, 1845-1995. Cape Town, Johannesburg and Pretoria: Human \& Rousseau. Brooke Simons, Phillida (1998) The life and work of Charles Bell. Vlaeberg: Fernwood Press.

Buchanan, Barbara I. (1934) Pioneer days in Natal. Pietermaritzburg: Shuter \& Shooter.

Bunn, David (1998) 'Whited sepulchres: On the reluctance of monuments', in blank__ architecture, apartheid and after, eds Hilton Judin and Ivan Vladislavić. Cape Town: David Philip, unpaginated.

Buranelli, Franceso, Robin C. Dietrick, Marco Bussagli, Cecilia Sica and Roberta Bernabei (2007) Between God and man: Angels in Italian art, the Annie Laurie Swaim Hearin Memorial Exhibition Series. Jackson, MS: University Press of Mississippi.

Burnett, Charles (1905) The 18th Hussars in South Africa: The records of a cavalry regiment during the Boer War 1899-1902. Winchester: Warren \& Son.

Burns, Michelle (2006) 'A completion of memory? Commemorating a decade of freedom in South Africa: 1994-2004', Eras 8 (November): unpaginated. www.arts.monash.edu.au/eras

Buthelezi, Mangosuthu Gatsha (1983) King Dingane ka Senzangakhona - second king of the Zulu nation, speech on 18 June 1983 to celebrate the unveiling of a memorial near the spot where he was assassinated and of a stone on his grave by King Zwelithini Goodwill ka Bhekuzulu, the eighth king of the Zulus. www.ifp.org.za/Archive/ MGButhelezi/1983/DOC00287.pdf.

Butler, Guy, ed. (1974) The 1820 settlers: An illustrated commentary. Cape Town: Human \& Rousseau.

Butterfield, Andrew (1997) The sculptures of Andrea del Verrocchio. New Haven: Yale University Press.

Cachet, Frans Lion (1882) De worstelstrijd der Transvalers: Aan het volk van Nederland verhaald. Amsterdam: J.H. Kruyt.

Cameron, J.T. (1994) Jan Smuts: An illustrated history. Cape Town: Human \& Rousseau.

Campana, Rossella (1991) Romano Romanelli: un' espressione del classicismo nella scultura del Novecento. Florence: Olschki.

Campana, Rossella (1998) 'Lo studio Bartolini-Romanelli in San Frediano', in Case di artisti in Toscana, ed. Roberto Paolo Ciardi. Milan: Silvana Editoriale, 167-253.

Campana, Rossella (2002) 'Lo studio Bartolini-Romanelli: Cento anni di storia della scultura a Firenze attraverso i gessi di una possibile, straordinaria gipsoteca', in Le gipsoteche in Toscana, eds Simonella Condemi and Claudio Stefanelli. Borgo a Buggiano: Comune Pescia, 81-87.

Campbell, James T., Matthew Pratt Guterl and Robert G. Lee, eds (2007) Race, nation and empire in American history. Chapel Hill: University of North Carolina Press.

Carruthers, Jane and Marion Arnold (1995) The life and work of Thomas Baines. Vlaeberg: Fernwood Press.

Carton, Benedict, John Laband and Jabulani Sithole, eds (2009) Zulu identities: Being Zulu, past and present. London: Hurst \& Company.

Čečot, Ivan (1998) “'Der Gestürzte” von Wilhelm Lehmbruck: ein Essay zum Problem der Beschreibung und Ausdeutung', in Festschrift für Christian Lenz: von Duccio bis Beckmann; anlässlich seines 60. Geburtstages am 11. Mai 1998, eds Felix Billeter, Helga Gutbrod, Christian Lenz and Andrea Pophanken. Frankfurt am Main: Blick in die Welt, 131-154.

Chapman, James (1868) Travels in the interior of South Africa, comprising fifteen years' hunting and trading, with journeys across the continent from Natal to Walvis Bay, and visits to Lake Ngami and the Victoria Falls. London: Bell \& Daldy.

Chase, Natal 1 (1843) = Chase, John Centlivres, ed. (1843) Natal: $A$ re-print of all notices and documents connected with the territory including a description of the country and a history of events from its discovery in 1498, to the mission of the Hon. H. Cloete L.L.D. \&c. in 1843, in two parts, part the first from A.D. 1498 to A.D. 1837. Graham's Town: R. Godlonton (facsimile reprint in one volume, British Library General Historical Collection, 1-135).

Chase, Natal 2 (1843) = Chase, John Centlivres, ed. (1843) Natal: $A$ re-print of all notices and documents connected with the territory including a description of the country and a history of events from its discovery in 1498, to the mission of the Hon. H. Cloete L.L.D. \&c. in 1843, in two parts, part the second from A.D. 1838 to A.D. 1843. 
Graham's Town: R. Godlonton (facsimile reprint in one volume, British Library General Historical Collection, 1-310).

Chaveas, Lucille M. (1993) 'A study of the quilted and corded "kappies" of the Voortrekker women and their resemblance to French white work quilting of the $17^{\text {th }}$ and $18^{\text {th }}$ centuries', Navorsing van die Nasionale Museum Bloemfontein 9.1 (March): 1-20.

Child, Daphne, ed. (1979) A merchant family in early Natal: Diaries and letters of Joseph and Marianne Churchill 1850-1880. Cape Town: Balkema.

Chipkin, Clive M. (1993) Johannesburg style: Architecture \& society 1880s-1960s. Cape Town: David Philip.

Claassen, Joe-Marie (2009) “'Yonder lies your hinterland”: Rhodes, Baker and the twisted strands of the South African architectural tradition', Akroterion: Journal for the Classics in South Africa 54: 69-86.

Clarke, Nicholas (2009) 'Uit Moerdijk se pen - man en media', unpublished Moerdyk Lecture 2 July. www.up.ac.za/ dspace/handle/2263/86

Cloete, Henry (1899) The history of the great Boer Trek and the origin of the South African republics, ed. W. BrodrickCloete (five lectures delivered to the Literary Society of Pietermaritzburg from 1852-55 by my grandfather, the Hon. Henry Cloete). London: John Murray.

Coertzen, Pieter (2012) 'Dordt and South Africa: The nature and challenges for Reformed Church polity in South Africa', Dutch Reformed Theological Journal 53.3-4: 78-89. http://ngtt.journals.ac.za/pub/article/view/252

Coetzee, Nico J. (1988) 'Die voorstelling van die Voortrekkers in die kuns', in Herdenkingsjaar 1988: Portugese, Hugenote en Voortrekkers, ed. J.S. Bergh. Pretoria: De Jager-Haum, 177-189.

Coetzee, Nico J. (1992) Pierneef, land and landscape: The Johannesburg Station panels in context. Johannesburg: CBM Publishing.

Coetzee, Nico J. (1995) 'Moerdijk and the Voortrekker Monument: The historical vocation of the artist', in Mechanisms of power, eds Rory Doepel and Andreas Bertold, 19-24 (conference proceedings of eleventh annual conference of the South African Association of Art Historians, University of the Witwatersrand, Johannesburg, July 1995).

Coetzer, Willem Hermanus (1947) My kwas vertel. Johannesburg: L\&S Boek en Kunssentrum.

Coetzer, Willem Hermanus (1951) 'Ultra-modern art as I see it', The Transvaal Educational News (June-July): 11-12.

Coetzer, Willem Hermanus (1974) 'The tapestries in the Voortrekker Monument, Pretoria', Africana Notes and News 21.3 (September): 87-102.

Coetzer, Willem Hermanus (1980) W.H. Coetzer 80. Roodepoort: CUM Boeke.

Cohen, Morris J. (1938) Anton van Wouw: Sculptor of South African life. Johannesburg: Radford Adlington. Collins, Robert O. (1990) Central and South African history. Princeton: Markus Wiener.

Cool Capital Catalogue (2016) https://issuu.com/coolcapital/docs/cool-capital-catalogue_2016/40

Coombes, Annie E. (2000) 'Translating the past: Apartheid monuments in post-apartheid South Africa', in Hybridity and its discontents: Politics, science, culture, eds Avtar Brah and Annie E. Coombes. London and New York: Routledge, 173-197.

Coombes, Annie E. (2003) History after apartheid: Visual culture and public memory in a democratic South Africa. Durham: Duke University Press.

Cooper, Alan A. (1980) The origins and growth of Freemasonry in South Africa, 1772-1876. MA thesis, University of Cape Town.

Cooper, Alan A. (1983) The effects of political, economic and social events on the order of Freemasons in South Africa, with some reference to the movement for the formation of a united Grand Lodge, 1772-1961. PhD thesis, Stellenbosch University. http://scholar.sun.ac.za/handle/10019.1/64775

Cooper, Alan A. (1986) The Freemasons of South Africa. Cape Town: Human \& Rousseau.

Cooper, C.A. (1973) Gerard Moerdyk: Sy lewe en werk. M Arch thesis, University of the Free State. http://scholar.ufs.ac.za:8080/xmlui/bitstream/handle/11660/719/CooperCA.pdf?sequence=1

Cope, A.T. (1979) 'Harry Camp Lugg’, Natalia: Journal of the Natal Society Foundation 9: 43-46.

Cornelius, Izak (2001) 'Van Karnak tot Kakamas: Die naleef van ou Egipte in die Suid-Afrikaanse boukuns', Akroterion: Journal for the Classics in South Natalia: Journal of the Natal Society Foundation 46: 75-91.

Cory, South Africa 3 (1919) = Cory, George E. (1919) The rise of South Africa: A history of the origin of South African colonisation and of its development towards the east from the earliest times to 1857, vol. 3. London: Longmans, Green and Co.

Cory, George (1924) 'The Retief-Dingaan treaty’ in Cory, Preller and Blommaert (1924), 1-12.

Cory, South Africa 4 (1926) = Cory, George E. (1926) The rise of South Africa: A history of the origin of South African colonisation and of its development towards the east from the earliest times to 1857, vol. 4. London: Longmans, Green and Co.

Cory, George, Gustav Preller and W. Blommaert (1924) ‘Die Retief-Dingaan-ooreenkoms', Annale van die Uniwersiteit van Stellenbosch, Serie B.1 (May).

Covi, Dario A. (2005) Andrea del Verrocchio: Life and work. Florence: Leo S. Olschki. 
Crais, C. (1992) White supremacy and black resistance in pre-industrial South Africa: The making of the colonial order in the Eastern Cape, 1770-1865. Cambridge: Cambridge University Press.

Crampton, Andrew (2001) 'The Voortrekker Monument, the birth of apartheid, and beyond', Political Geography 20: 221-246.

Crump, Alan and Raymund van Niekerk (1988) Public sculpture and reliefs: Cape Town. Cape Town: Clifton Publications.

Crump, Alan and Raymund van Niekerk (n.d.) Public sculpture: Pretoria. Unpublished proof.

Cubbin, Anthony E. (1980) A study in objectivity: The death of Piet Retief. MA thesis, University of the Orange Free State.

Cubbin, Anthony E. (1988) 'The English alliance with the Voortrekkers against the Zulus during March and April 1838', Historia: Journal of the Historical Association of South Africa 33.2: 63-73.

Cumming-George, L. (1933) Architecture in South Africa 1. Cape Town: The Speciality Press of S.A.

Currey, Ralph N., ed. (1968) Letters \& other writings of a Natal sheriff: Thomas Phipson 1815-76, selected and introduced by Ralph N. Currey. Cape Town: Oxford University Press.

Dalbiac, Philip H. (1902) History of the 45th: 1st Nottinghamshire Regiment (Sherwood Foresters). London: Swan Sonnenschein.

D’Assonville, V.E. (2007) Blood River. Pretoria: Marnix (first printed 2000).

Davenport, T.R.H. (1977) South Africa: A modern history. London: Macmillan.

Davis, Whitney (2011) A general theory of visual culture. Princeton: Princeton University Press.

Davis, Whitney (2018) 'Countering contrapposto', in The classical now, eds Evelyn S. Welch, Christian Levett and Michael Squire. London: Elephant Publishing and King’s College London, 80-89.

De Beer, Andre (1969) Die lewe en werk van die skilder W.H. Coetzer en sy kultuurhistoriese betekenis. MA dissertation, University of Pretoria. http://repository.up.ac.za/handle/2263/30209

De Jager, Cornelius (2013) 'The Voortrekker Monument' (interview and CD).

De Jongh, P.S. (1977) Die lewe van Erasmus Smit. Pretoria: HAUM.

De Jongh, P.S. (1988) ‘Perspektiefstelling oor omstrede aangeleenthede van die Groot Trek', Historia: Journal of the Historical Association of South Africa 33.2: 27-37.

De Kamper, Gerard and Chris de Klerk (2011) Sculptured: The complete works of Fanie Eloff. Pretoria: University of Pretoria.

Delegorgue, Travels 1 (1990) = Delegorgue, Adulphe (1990) Adulphe Delegorgue's travels in southern Africa, vol. I, trans. Fleur Web, introduced and annotated by Stephanie J. Alexander and Colin de B. Webb. Durban: Killie Campbell Africana Library, and Pietermaritzburg: University of Natal Press (first published in 1847 as Voyages dans l'Afrique Australe notamment dans le territoire de Natal dans celui des Cafres Amazoulous et Makatisses et jusqu'au tropique du Capricorne - Durant les années 1838, 1839, 1840, 1841, 1842, 1843, \& 1844 - Avec dessins et de cartes, vol. I. Paris: Depot de Librairiè, Rue des Moulins, 8).

Delegorgue, Travels 2 (1997) = Adulphe (1997) Adulphe Delegorgue's travels in southern Africa, vol. II, trans. Fleur Web, introduced and annotated by Stephanie J. Alexander and Bill Guest. Durban: Killie Campbell Africana Library, and Pietermaritzburg: University of Natal Press (first published in 1847 as Voyages dans l'Afrique Australe notamment dans le territoire de Natal dans celui des Cafres Amazoulous et Makatisses et jusqu'au tropique du Capricorne - Durant les années 1838, 1839, 1840, 1841, 1842, 1843, \& 1844 - Avec dessins et de cartes, vol. II. Paris: Depot de Librairiè, Rue des Moulins, 8).

Delmont, Elizabeth (1993) 'The Voortrekker Monument: Monolith to myth', South African Historical Journal 29 (November): 76-101.

Die saamwerk (1938) = Die saamwerk: Eeufees-gedenkuitgawe, Desember 1938 (1938). Estcourt, Natal: SaamwerkUnie van Natalse Kultuurvereniging.

Dobošová, Jela (2009) 'Calvinism in the context of the Afrikaner nationalist ideology', Asian and African Studies 78.2: 305-323. https://www.sav.sk/journals/uploads/092611248_Dobo\%C5\%A1ov\%C3\%A1.pdf

Donaldson, Peter (2013) Remembering the South African War: Britain and the memory of the Anglo-Boer War, from 1899 to the present. Liverpool: Liverpool University Press.

Donato, Attanasio (2003) Ancient white marbles: Analysis and identification by paramagnetic resonance spectroscopy. Rome: 'L'Erma' di Bretschneider.

Doucakis, Alkis (2000) ““De Heer Maritz Zijn Lager” at the Zuikerboschrand, Sep.-Dec. 1837’, Historia: Journal of the Historical Association of South Africa 45.2: 502-528.

Dreyer, Andries (1932) Die Voortrekkers en hul kerk: Sketse uit die kerklike geskiedenis van die Groot Trek. Cape Town: Nasionale Pers.

Drury, Edward G. Dru (1928) Records of the Albany Lodge, No. 389, EC meeting at Grahamstown, S. Africa, from 1828 to 1928. Grahamstown: privately published, Grocott \& Sherry.

$D S A B 1$ (1968) = Dictionary of South African biography, ed. W.J. de Kock. Cape Town: Nasionale Boekhandel.

DSAB 2 (1972) = Dictionary of South African biography, eds W.J. de Kock (until 1970) and D.W. Krüger (since 1971). Cape Town and Johannesburg: Tafelberg-Uitgewers. 
DSAB 3 (1977) = Dictionary of South African biography, eds D.W. Krüger (until 1972) and C.J. Beyers (since 1973). Cape Town and Johannesburg: Tafelberg-Uitgewers.

DSAB 4 (1981) = Dictionary of South African biography, ed. C.J. Beyers. Durban and Pretoria: Butterworth \& Co.

DSAB 5 (1987) = Dictionary of South African biography, eds C.J. Beyers and J.L. Basson. Pretoria: Human Sciences Research Council.

Duffey, Alexander E. (1981) Anton van Wouw, 1862-1945, en die Van Wouwhuis. Pretoria: University of Pretoria.

Duffey, Alexander E. (1982) The Equestrian statue: A study of its history and the problems associated with its creation. PhD thesis, University of Pretoria. http://repository.up.ac.za/handle/2263/41808

Duffey, Alexander E. (1993) 'Laurika Postma', in Our Art 4, compilers Albert Werth and Frieda Harmsen. Pretoria: Foundation for Education, Science and Technology, 50-57.

Duffey, Alexander E. (2006) 'n Egte lugkasteel: Moerdijk, Van Wouw en die Voortrekkermonument', Suid-Afrikaanse Tydskrif vir Kultuurgeskiedenis 20.2: 22-41.

Duffey, Alexander E. (2008) 'Dr Peter Kirchhoff (1893-1978)’, Africana Society Pretoria Yearbook 22: 150-151.

Duffey, Van Wouw (2008) = Duffey, Alexander E. (2008) Anton van Wouw: The smaller works. Pretoria: Protea Boekhuis.

Duffey, Alexander E., Gerard de Kamper and Daniel Mosako (2010) Anton van Wouw. Pretoria: Department of Arts, University of Pretoria.

Duffey, Alexander E., Sian Tiley-Nel, Gerard de Kamper and Joey Ernst (2008) The art \& heritage collection of the University of Pretoria. Pretoria: University of Pretoria.

Duminy, Andrew and Bill Guest, eds (1989) Natal and Zululand from earliest times to 1910: A new history. Pietermaritzburg: University of KwaZulu-Natal Press and Shuter \& Shooter.

Du Plessis, Antoinette (1996) The Renzo Vignali artistic foundry: A history of its establishment and contribution to bronze sculpture in South Africa, 1931-c.1958. MA thesis, University of the Witwatersrand.

Du Plessis, W. and J.J. Olivier (1987) 'Laurika Postma', Tydskrif vir Geesteswetenskappe 27.2: 114-120.

Du Preez, Sophia J. (1974) History, homes and customs of the Voortrekkers (Studies by the National Cultural History Museum and Open Air Museum, 4). Pretoria: Voortrekker Monument Museum.

Du Spies, F.J. (1988) ‘Onsekerheid in verband met die gelofte van 1838', Historia: Journal of the Historical Association of South Africa 33.2: 51-62.

Dutch Reformed Church and Freemasonry (1940) = Die N.G. Kerk in S.A. en die Vrymesselary (1940). Cape Town: S.A. Bybelvertaling.

Du Toit, André (1983) ‘No chosen people: The myth of Calvinist origins of Afrikaner nationalism and racial ideology', American Historical Review 88 (October): 920-952.

Du Toit, André and Hermann Giliomee (1983) Afrikaner political thought: Analysis and documents 1, 1780-1850. Cape Town: David Philip.

Du Toit, A.G. and Louis Steenkamp (1938) Bloedrivierse eeufees-gedenkboek: 16 December 1938. Pietermaritzburg: Die Natalse Pers.

Duvenage, Gedenktrek (1988) = Duvenage, Gert D.J. (1988) Die gedenktrek van 1938: 'n Edevaart en 'n kruistog. Pretoria: Gutenberg Boekdrukkers.

Duvenage, Gelofte (1988) = Duvenage, Gert D.J. (1988) Die Groot Trek: Die eerste drie jaar, vol. 3, 1838 Die gelofte. Pretoria: 'n Afrikanervolkswag-publikasie.

Duvenage, Manifes (1988) = Duvenage, Gert D.J. (1988) Die Groot Trek: Die eerste drie jaar, vol. 2, 1837 Die manifes. Pretoria: 'n Afrikanervolkswag-publikasie.

Duvenage, Vegkop (1988) = Duvenage, Gert D.J. (1988) Die Groot Trek: Die eerste drie jaar, vol. 1, 1836 Vegkop. Pretoria: 'n Afrikanervolkswag-publikasie.

Ehlers, Anton (2005) 'Apartheid mythology and symbolism desegregated and re-invented in the service of nation building in the new South Africa: The covenant and the Battle of Blood/Ncome River' (5ème colloque international 'Les mythes fondateurs de la nouvelle Afrique du Sud', Université de La Réunion, 25-29 mars 2003, ed. Claude Feral), Alizés. Revue angliciste de La Réunion 24: 1-31.

Eksteen, Louis J. (2006) 'The historical importance of the farm Zaay Lager', October 2006. Heritage Foundation Archives at the Voortrekker Monument, Pretoria, ES 9/5/1/5/1 vol. 1.

Emiliani, Andrea and Michela Scolaro (2002) Raffaello: la stanza della Segnatura. Milan: Electa.

Engelbrecht, Stephanus P. et al. (1950) 'Die Geloftekerk', in Almanak van die Nederduitsch Hervormde Kerk von Afrika, 79-102.

Enwezor, Okwui and Rory Bester, eds (2013) Rise and fall of apartheid: Photography and the bureaucracy of everyday life, exhibition catalogue, 14 September 2012-6 January 2013. New York: International Center of Photography and Prestel.

Erlank, W.J. du P., Hendrik Bernardus Thom and I.J. Rousseau (1950) Historiese rekord van die opening van Voortrekkermonument, Pretoria, Transvaal, South Africa, 16de Desember, 1949 - Historical record of the opening of Voortrekker Monument, Pretoria, Transvaal, South Africa, December 16th, 1949. Johannesburg: Insercor Industrial Services. 
Esche-Braunfels, Sigrid (1993) Adolf von Hildebrand (1847-1921). Berlin: Deutscher Verlag für Kunstwissenschaft. Etherington, Norman (1991) 'The Great Trek in relation to the Mfecane: A reassessment', South African Historical Journal 25: 3-21.

Etherington, Norman (2001) The Great Treks: The transformation of southern Africa, 1815-1854. London: Pearson Education.

Etherington, Norman, Patrick Harries and Bernard Mbenga (2010) 'From colonial hegemonies to imperial conquest, 1840-1880', in Hamilton, Mbenga and Ross (2010), 319-391.

Evans, Richard (2007) 'Perspectives on post-colonialism in South Africa: The Voortrekker Monument's classical heritage', in Classics in post-colonial worlds, eds Lorna Hardwick and Carol Gillespie. Oxford: Oxford University Press, 141-156.

Eybers, George von Welfling (1918) Select constitutional documents illustrating South African history 1795-1910. London: George Routledge, and New York: E.P. Dutton \& Co.

Fauerbach, Ulrike (2017) Der große Pylon des Horus-Tempels von Edfu: Architektur und Bautechnik eines monumentalen Torbaus der Ptolemaierzeit, Archäologische Veröffentlichungen des Deutschen Archäologischen Instituts, v. 122. Wiesbaden: Harrassowitz.

Faure, David P. (1907) My life and times. Cape Town: Juta. https://ia600208.us.archive.org/9/items/mylifetimes00faur/mylifetimes00faur.pdf

Faust, Stephan (2012) Schlachtenbilder der römischen Kaiserzeit, Erzählerische Darstellungskonzepte in der Reliefkunst von Traian bis Septimius Severus. Rahden/Westf.: Marie Leidorf.

Fehr, Burkhard (1979) Bewegungsweisen und Verhaltensideale. Physiognomische Deutungsmöglichkeiten der Bewegungsdarstellung an griechischen Statuen des 5. und 4. Jhs. v. Chr. Bad Bramstedt: Moreland Editions.

Ferreira, Ockert Jacobus Olivier (1970) Die geskiedenis van die Sentrale Volksmonumentekomitee. MA thesis, University of Pretoria. http://oatd.org/oatd/record?record=oail:UP\:etd-05082012-130402

Ferreira, Ockert Jacobus Olivier (1975) 'n Volk se hulde: Die geskiedenis van die Sentrale Volksmonumentekomitee. Johannesburg: Perskor.

Fisher, Roger C. (2003) 'Gerard Moerdijk: The formative years', South African Journal of Art History 18: 28-37.

Fisher, Roger C. (2006) 'Baker and Moerdijk: A shared legacy apart', South African Journal of Art History 21.2: 124-136.

Fisher, Roger C. and Nicholas J. Clarke (2010) ‘Gerard Moerdijk: Death and memorializing in his architecture for the Afrikaner nationalist project’, South African Journal of Art History 25.2: 151-160.

Fourie, Johan (2006) The South African poor white problem in the early $20^{\text {th }}$ century: Lessons for poverty today, Stellenbosch Economic Working Papers, 14/06. University of Stellenbosch. www.ekon.sun.ac.za/ wpapers/2006/wp142006/wp-14-2006.pdf

Franken, Johan L.M. (1949) Piet Retief se lewe in die kolonie. Cape Town and Pretoria: J.H. de Bussy.

Fransen, Hans (1988) 'Architecture: The new amidst the old', in Laband and Haswell (1988), 55.

Fransen, Hans and Mary Alexander Cook (1965) The old houses of the Cape: A survey of the existing buildings in the traditional style of architecture of the Dutch-settled regions of the Cape of Good Hope. Cape Town: A.A. Balkema.

Freschi, Federico (1994) 'Big business beautility: The Old Mutual building, Cape Town, South Africa', Journal of Decorative and Propaganda Arts 20: 39-57.

Freschi, Federico (2004) 'Imagining fusion: The politics of South Africanism as reflected in the decorative programme of the Pretoria City Hall', de arte 69: 1-25.

Freschi, Federico (2005) 'The fine art of fusion: Race, gender and the politics of South Africanism as reflected in the decorative programme of South Africa House, London (1933)', de arte 71: 14-34.

Freschi, Federico (2006) The politics of ornament: Modernity, identity, and nationalism in the decorative programmes of selected South African public and commercial buildings 1930-1940. PhD thesis, University of the Witwatersrand. http://wiredspace.wits.ac.za/handle/10539/2014

Freschi, Federico (2009) 'The business of belonging: Volkskapitalisme, modernity and the imaginary of national belonging in the decorative programmes of selected commercial buildings in Cape Town, South Africa, 1930-1940', South African Historical Journal 61.3: 521-549. http://dx.doi.org/10.1080/02582470903189741

Freschi, Afrikaner nationalism (2011) = Freschi, Federico (2011) 'Afrikaner nationalism, modernity and the changing canon of "high art"', in Visual century: South African art in context, vol. 2, ed. Lize van Robbroeck. Johannesburg: Wits University Press, 8-25.

Freschi, Unity in diversity (2011) = Freschi, Federico (2011) “"Unity in diversity”: The representation of white nationalism in the decorative programmes of public buildings in the 1930s', in Visual century: South African art in context, vol. 1, ed. Jillian Carman. Johannesburg: Wits University Press, 156-173.

Freschi, Frederico (2019) 'Art Deco, modernity, and the politics of ornament in South African architecture', in The Routledge companion to art deco, eds Bridget Elliot and Michael Windover. New York and Abingdon-on-Thames: Routledge, 253-271. 
Fuhrmann, Dietmar, ed. (1992) Profession ohne Tradition: 125 Jahre Verein der Berliner Künstlerinnen, ein Forschungs- und Ausstellungsprojekt der Berlinischen Galerie in Zusammenarbeit mit dem Verein der Berliner Künstlerinnen. Berlin: Kupfergraben.

Fuller, Trigardt's trek (1932) = Fuller, Claude (1932) Louis Trigardt's trek across the Drakensberg, 1837-1838, ed. Leo Fouché. Cape Town: Van Riebeeck Society.

Gamedze, Thuli (2015) 'Heritage for sale: Bronze casting and the colonial imagination', Artthrob 20 November, http://artthrob.co.za/2015/11/20/heritage-for-sale-bronze-casting-and-the-colonial-imagination/.

Gardiner, Allen F. (1836) A journey to the Zoolu country in South Africa: Undertaken in 1835. London: William Crofts, Chancery Lane.

Geniale beeldhouer (1949) = ‘Geniale beeldhouer en skilder van Brakpan’, Voorslag November/December: 15 (author unknown).

Gerdener, Gustav B.A. (1925) Sarel Cilliers: Die vader van Dingaansdag. Lewenskets van die grote Voortrekker, 3rd ed. Pretoria: J.L. van Schaik (1st ed. 1919, Cape Town: Griffiths).

Giblin, John and Chris Spring (2016) South Africa: The art of a nation, exhibition catalogue British Museum. London: Thames and Hudson.

Giffard, C. Anthony, ed. (1981) The reminiscences of John Montgomery. Cape Town: A.A. Balkema for Rhodes University, Grahamstown.

Giliomee, Hermann (2003) The Afrikaners: Biography of a people. Cape Town: Tafelberg Publishers, and Virginia: University of Virginia Press.

Giliomee, Hermann and Bernard Mbenga (2007) New history of South Africa. Cape Town: Tafelberg.

Gillis, John, ed. (1994) Commemorations: The politics of national identity. Princeton: Princeton University Press.

Girshick, Paula (2004). ‘Ncome Museum/Monument: From reconciliation to resistance', in Museum Anthropology 27: 25-36.

Gledhill, Eily and Jack (1980) In the steps of Piet Retief. Cape Town: Human \& Rousseau.

Glenn, Ian (2007) 'Classical Black', in English in Africa 34.2: 19-33.

Glover, Michael (2019) 'A cattle-centred history of South Africa?' in Nature conservation in southern Africa: Morality and marginality - towards sentient conservation? eds Jan-Bart Gewald, Marja Spierenburg and Harry Wels. Leiden and Boston: Brill.

Goldblatt, David (1998) South Africa: The structure of things then, with an essay by Neville Dubow. Cape Town: Oxford University Press.

Gordon, Ruth E. and Mat Louwrens (1984) Victorian Pietermaritzburg. Springfield, South Africa: Village Publishers.

Gosselink, Martine, Maria Holtrop and Robert Ross, eds (2017) Good Hope: South Africa and the Netherlands from 1600, exhibition catalogue Rijksmuseum Amsterdam. Nijmegen: Vantilt.

Graßhoff, Gerd, Michael Heinzelmann and Markus Wäfler, eds (2009) The Pantheon in Rome: Contributions to the conference, Bern, November 9-12, 2006, Pantheon I. Bern: Bern Studies in the History and Philosophy of Science.

Green, Georgina (2014) The majesty of the people: Popular sovereignty and the role of the writer in the 1790s. Oxford: Oxford University Press.

Greenwall, Ryno (1992) Artists \& illustrators of the Anglo-Boer War. Vlaeberg: Fernwood Press.

Grey, H. George (1853) The colonial policy of Lord John Russell's administration, 2nd ed. London: R. Bentley.

Grobler, Elda (2005) Collections management practices at the Transvaal Museum, 1913-1964, anthropological, archaeological and historical. DPhil thesis, University of Pretoria. http://repository.up.ac.za/ handle $/ 2263 / 24550$ ?show=full

Grobler, Elda and Fransjohan Pretorius (2008) 'Kotie Roodt-Coetzee se bydrae tot die kultuurhistoriese museumwese in Suid-Afrika - die Transvaalmuseumfase, 1933-1964', South African Journal of Cultural History 22.1: 112-135.

Grobler, Jackie (2001) Ontdek die Voortrekkermonument - discover the Voortrekker Monument. Pretoria: Grourie Entrepreneurs.

Grobler, Jackie (2010) 'Afrikaner- en Zoeloeperspektiewe op die Slag van Bloedrivier, 16 Desember 1838', Tydskrif vir Geesteswetenskappe 50.3: 363-382.

Grobler, Jackie (2011) 'The Retief massacre of 6 February 1938 revisited’, Historia: Journal of the Historical Association of South Africa 56.2: 113-132.

Grobler, Jackie (2012) Monumentale erfenis: 'n gids tot 50 Afrikaner-gedenktekens. Pretoria: Kontak-Uitgewers.

Groenewald, P.W.J. (1964) Die Voortrekker-Gedenkkerk Pietermaritzburg. Durban: Drakensbergpers.

Groenewald, P.W.J. and T.V. Bresler (1955) Herbevestiging van die gelofte: Gedenkboek Pietermaritzburg Desember 1955. Pietermaritzburg: Natalse Pers.

Grummond, Nancy T. de and Brunilde S. Ridgway, eds (2000) From Pergamon to Sperlonga: Sculpture and context. Berkeley, Los Angeles and London: University of California Press.

Grundlingh, Albert (2002) ‘The National Women's Monument: The making and meaning in Afrikaner memory of the South African War', in Writing a wider war: Rethinking gender, race, and identity in the South African War, 
1899-1902, eds Greg Cuthbertson, Albert Grundlingh and Mary-Lynn Suttie. Athens: Ohio University Press, $18-36$.

Grundlingh, Albert (2009) 'A cultural conundrum? Old monuments and new regimes: The Voortrekker Monument as symbol of Afrikaner power in a postapartheid South Africa', in Contested histories in public space: Memory, race, and nation, eds Daniel J. Walkowitz and Lisa Maya Knauer. Durham and London: Duke University Press, 157-177.

Grundlingh, 'The meaning of the Women's Monument: Then and now' (2013)= Grundlingh, Albert (2013) 'The meaning of the Women's Monument: Then and now', in Nasson and Grundlingh (2013), 226-245.

Grundlingh, 'Why concentration camps?' (2013) = Grundlingh, Albert (2013) 'Why concentration camps?' in Nasson and Grundlingh (2013), 22-43.

Grundlingh, Albert and Siegfried Huigen, eds (2011) Reshaping remembrance: Critical essays on Afrikaans places of memory. Amsterdam: Rozenberg Publishers.

Grundlingh, Albert and Hilary Sapire (1989) 'From feverish festival to repetitive ritual? The changing fortunes of Great Trek mythologies in an industrializing South Africa, 1938-1988', South African Historical Journal 21: 19-37.

Guest, Bill W.R. (2012) Trek and transition: A history of the Msunduzi and Ncome museums, incorporating the Voortrekker Complex, 1912-2012. Pietermaritzburg: Msunduzi and Ncome Museums.

Guide for the apprentice Freemason (1934) = A guide for the apprentice Freemason. A translation [by Gerard A. Leyds] of the original, authorised by Resolution of Grand East, passed on the 15th June, 1930 (1934). Cape Town: Provincial Grand Lodge in South Africa.

Hagg, Gerard (1989) 'Coert Steynberg en die opkoms van die Afrikaner-nationalisme: 1930-40', Journal of South African Art History 4.1-2 (June): 12-19.

Hale, F. (2003) 'The Great Trek as exodus in J.D. Kestell's and N. Hofmeyr’s De voortrekkers of Het Dagboek van Izak van der Merwe: Research', Acta Theologica 23.1: 54-70.

Hall, Martin (2000) Archaeology and the Modern World. Colonial Transcripts in South Africa and the Chesapeake. London and New York: Routledge.

Hamilton, Carolyn (1998) Terrific majesty: The powers of Shaka Zulu and the limits of historical invention. Cambridge, MA: Harvard University Press.

Hamilton, Carolyn, Bernard K. Mbenga and Robert Ross, eds (2010) The Cambridge history of South Africa, vol. 1. Cambridge: Cambridge University Press.

Handler, Richard (1994) 'Is “identity” a useful cross-cultural concept?' in Commemorations: The politics of national identity, ed. John Gillis. Princeton, NJ: Princeton University Press, 27-40.

Harington, Andrew L. (1972) The Great Trek. London: Edward Arnold.

Harington, Andrew L. (1973) The Graham's Town Journal and the Great Trek, 1834-1843. Johannesburg: Perskor for the Government Printer.

Harmsen, Frieda (1985) Looking at South African art: A guide to the study and appreciation of art. Pretoria: J.L. van Schaik.

Haswell, Robert F. (1988) 'Pieter Mauritz Burg: The genesis of a Voortrekker hoofdplaats', in Laband and Haswell (1988), 24-27.

Hattersley, Alan F. (1936) More annals of Natal, with historical introductions and notes. London: Frederick Warne \& Co.

Havemann, P.J. (1959?) My mother: A Voortrekker. Pietermaritzburg: The Natal Press.

Hees, Edwin (1996) ‘The Voortrekkers on film: From Preller to pornography', Critical Arts: South-North Cultural and Media Studies 10.1: 1-22.

Henderson, John and Stig Miss (2005) The triumph of art at Thorvaldsens Museum: 'Løve' in Copenhagen. Copenhagen: Museum Tusculanum Press, University of Copenhagen.

Henning, Cosmo G. (1975) Graaff-Reinet: A cultural history 1786-1886. Cape Town: Cape \& Transvaal Printers.

Henning, Elrica E. (2014) The cultural significance of the Church of the Vow in Pietermaritzburg, KwaZulu-Natal. MA thesis, University of Pretoria. http://repository.up.ac.za/handle/2263/50916

Henseleit, Frank (2005) Der Bildhauer Bernhard Bleeker (1881-1968): Leben und Werk. PhD thesis, Augsburg University. http://opus.bibliothek.uni-augsburg.de/opus4/frontdoor/index/index/docld/467

Herwitz, Daniel (2012) Heritage, culture, and politics in the postcolony. New York: Columbia University Press.

Heunis, Victoria Regina (2008) Monumente en gedentekens opgerig tydens die simboliese ossewatrek en Voortrekkereeufees, 1938. MA thesis, University of Pretoria. http://repository.up.ac.za/handle/2263/29552

Heusinger von Waldegg, Joachim (1979) 'Richard Luksch: Zur Modernität eines Bildhauers', in Richard Luksch Helmut R. Leppien: Elena Luksch-Makowsky, eds Joachim Heusinger von Waldegg and Ida and Richard Dehmel. Hamburg: Christians, 5-12 figs. 1-36a.

Heymans, Riana (1986) The Voortrekker Monument, Pretoria. Pretoria: Board of Control of the Voortrekker Monument. 
Heymans, Riana and Salomé Theart-Peddle (2009) The Voortrekker Monument, visitor's guide and souvenir. Pretoria: Voortrekker Monument and Nature Reserve (originally compiled by Heymans 1986, new joint edition 2007, revised in 2009).

Hildebrand, Adolf (1901) Das Problem der Form in der bildenden Kunst, 3rd ed. Strassburg: Heitz (1st ed. 1893; English trans. Max F. Meyer and Robert Morris Ogden, The problem of form in painting and sculpture. New York: G.E. Stechert, 1907).

Hilliard, Olive M. and Brian L. Burtt (1987) The botany of the southern Natal Drakensberg. Kirstenbosch: National Botanic Gardens.

Hintrager, Oskar (1938) 'Die Voortrekker-Jahrhundertfeier in Südafrika’, Koloniale Rundschau. Zeitschrift für koloniale Länder-, Völker- und Staatenkunde 29.5/6: 273-278.

Hobbs, Philippa (2006) 'Introduction', in Messages and meaning: The MTN art collection, ed. P. Hobbs. Johannesburg: David Krut Publishing, 13-27.

Hockly, Harold Edward (1957) The story of the British settlers of 1820 in South Africa, 2nd enlarged and revised ed. Cape Town and Johannesburg: Juta \& Co. (1st ed. 1948).

Hoeksema, Homer C. (2013) The voice of our fathers: An exposition of the Canons of Dordrecht, 2nd ed. Jenison, Mich.: Reformed Free Publishing Association (1st ed. 1980).

Hölscher, Tonio (1967) Victoria Romana: Archäologische Untersuchungen zur Geschichte und Wesensart der römischen Siegesgöttin von den Anfängen bis zum Ende des 3. Jhs. n. Chr. Mainz am Rhein: Philipp von Zabern.

Hölscher, Tonio (2003) ‘Körper, Handlung und Raum als Sinnfiguren in der griechischen Kunst und Kultur’, in Sinn (in) der Antike: Orientierungssysteme, Leitbilder und Wertkonzepte im Altertum, eds Heinrich T. Grütter, Karl-Joachim Hölkeskamp, Jörn Rüsen and Elke Stein-Hölkeskamp. Mainz am Rhein: Philipp von Zabern, 163-192.

Hölscher, Tonio (2017) 'Ideologie der Realität - Realität der Ideologie. Narrative Struktur, Sachkultur und (Un-)Sichtbarkeit eines bildlichen Kriegsberichts', in Mitthof and Schörner (2017), 15-38.

Hölscher, Tonio (2018) Visual power in ancient Greece and Rome: Between art and social reality. Oakland, California: University of California Press.

Hölscher, Tonio (2019) Krieg und Kunst im antiken Griechenland und Rom: Heldentum, Identität, Herrschaft, Ideologie. Berlin and Boston: De Gruyter.

Hoffmann, Stefan-Ludwig (1994) 'Sakraler Monumentalismus um 1900: Das Leipziger Völkerschlachtdenkmal', in Der politische Totenkult, Kriegerdenkmäler in der Moderne, eds Reinhart Koselleck and Michael Jeismann. Munich: Wilhelm Fink Verlag, 249-280.

Hofmeyr, Isabel (1987) 'Building a nation from words: Afrikaans literature and ethnic identity, 1902-1924', in The politics of race, class and nationalism in twentieth-century South Africa, eds Shula Marks and Stanley Trapido. London: Longman, 95-123.

Hofmeyr, Isabel (1988) ‘Popularizing history: The case of Gustav Preller’, The Journal of African History 29.3: 521-535.

Hofstede, Helperus J. (1876) Geschiedenis von den Oranje-Vrijstaat, in verband met eene korte geschiedenis der aangrenzende kolonien, vooral der Kaapkolonie, volgens bezworen verklaringen der voortrekkers, en de archieven, documenten en proclamatien, met schetsen en kaarten opgeluisterd. 'S Gravenhage: D.A. Thieme.

Holden, William Clifford (1855) History of the colony of Natal, South Africa. London: Alexander Heylin, and Graham's Town: Godlonton, White and Co.

Hudson, Kevin W. (2011) 19th century tragedy, victory, and divine providence as the foundations of an Afrikaner national identity. MA thesis, Georgia State University, Atlanta. http://scholarworks.gsu.edu/cgi/viewcontent. cgi? article $=1044 \&$ context $=$ history_theses

Huisgenoot (1936) Uitgawe die Groote Trek, 11 December 1936.

Huisgenoot (1938) Gedenkuitgawe gewy aan die Groot Trek, December 1938.

Hulley, Richard B. (1880) Zululand under Dingaan: Account of the Rev. Mr. Owen's visit to Zululand in the year 1837, as related by Mr. R.B. Hulley. Cape Town: Cape Monthly magazine.

Hulumende Maphalala, Jobulani S. (1997) 'Prince Shingana Kampande and white supremacy 1838-1910', in Settlement, conflict and development in Natal: A selection of papers presented at the Natal History Workshop, University of Natal, Pietermaritzburg, April 3-4, 1997. Pietermaritzburg: Department of Historical Studies, University of Natal.

Hutchison, Yvette (2013) South African performance and archives of memory. Manchester: Manchester University Press.

Hutter, Peter (1990) Die feinste Barbarei: Das Völkerschlachtdenkmal bei Leipzig. Mainz am Rhein: Philipp von Zabern.

Inglis, Kenneth Stanley (2005) Sacred places: War memorials in the Australian landscape. Melbourne: Melbourne University Press (1st ed. 1998). 
Jaffé, David (2009) Rubens's Massacre of the Innocents: The Thomson Collection at the Art Gallery of Ontario, with a contribution by Giovanna Tonelli. Toronto: Skylet and the Art Gallery of Ontario, and Seattle, WA: University of Washington Press.

Jain, Gora (2002) Die anthropologisch fundierte Werkidee im Oeuvre der Bildhauerin Milly Steger (1881-1948). Herbolzheim: Centaurus.

James Stuart Archive 1 (1976) = Webb, Colin de B. and John B. Wright, eds (1976) The James Stuart Archive of recorded oral evidence relating to the history of the Zulus and neighbouring peoples, vol. 1. Pietermaritzburg: University of Natal Press, and Durban: Killie Campbell Africana Library.

James Stuart Archive 3 (1982) = Webb, Colin de B. and John B. Wright, eds (1982) The James Stuart Archive of recorded oral evidence relating to the history of the Zulus and neighbouring peoples, vol. 3. Pietermaritzburg: University of Natal Press, and Durban: Killie Campbell Africana Library.

James Stuart Archive 4 (1986) = Webb, Colin de B. and John B. Wright, eds (1986) The James Stuart Archive of recorded oral evidence relating to the history of the Zulus and neighbouring peoples, vol. 4. Pietermaritzburg: University of Natal Press, and Durban: Killie Campbell Africana Library.

James Stuart Archive 5 (2001) = Webb, Colin de B. and John B. Wright, eds (2001) The James Stuart Archive of recorded oral evidence relating to the history of the Zulus and neighbouring peoples, vol. 5. Pietermaritzburg: University of Natal Press, and Durban: Killie Campbell Africana Library.

James Stuart Archive 6 (2014) = Webb, Colin de B. and John B. Wright, eds (2014) The James Stuart Archive of recorded oral evidence relating to the history of the Zulus and neighbouring peoples, vol. 6. Pietermaritzburg: University of Natal Press, and Durban: Killie Campbell Africana Library.

Jansen, Ernest G. (1938) Die Voortrekkers in Natal: Opstelle. Cape Town: Nasionale Pers.

Jansen, Ernest G. (1939) ‘§12. The Voortrekker Centenary’, reprinted from South Africa official year book, no. 20: 1-10 (Box VP94 1/13/4/8, Jansen file, ARCA, University of the Free State, Bloemfontein).

Jenkins, Ian (1992) Archaeologists and aesthetes in the sculpture galleries of the British Museum 1800-1939. London: British Museum Press.

Jeppesen, Kristian (2002) The Maussolleion at Halikarnassos: Reports of the Danish archaeological expedition to Bodrum, vol. 5, The superstructure: A comparative analysis of the architectural, sculptural, and literary evidence. Aarhus: Aarhus University Press.

Jolly, Pieter (2005) 'Sharing symbols: A correspondence in the ritual dress of black farmers and the southeastern San', South African Archaeological Society Goodwin Series 9: 86-100.

Jooste, Derek (2016) 'The life of iconic artist, sculptor and designer Ernest Ullmann'. http://www.theheritageportal. co.za/article/life-iconic-artist-sculptor-and-designer-ernest-ullmann

Jorgensen, Sara C. (2009) The American Zulu mission and the limits of reform: Natal, South Africa, 1835-1919. PhD thesis, Princeton University.

Joubert, Jurie J. (1983) Die geskiedskrywing in die Huisgenoot, 1923-1949. MA thesis, University of South Africa. https://core.ac.uk/download/pdf/43176570.pdf

Kavanagh, Gaynor (1988) 'Museum as memorial: The origins of the Imperial War Museum', Journal of Contemporary History 23: 77-97.

Keller, Katrin and Hans-Dieter Schmidt (1995) Vom Kult zur Kulisse: Das Völkerschlachtdenkmal als Gegenstand der Geschichtskultur. Leipzig: Leipziger Universitäts-Verlag.

Kennedy, R.F. (1971) Catalogue of pictures in the Africana Museum, vol. 6. Johannesburg: Africana Museum.

Kenny, R.U. (1976) Piet Retief: The dubious hero. Cape Town and Pretoria: Human \& Rousseau.

Kent, John P.C., Bernhard Overbeck and Armin von Stylow, eds (1973) Die römische Münze. Munich: Hirmer.

Keppel-Jones, Arthur, ed. (1960) Philipps, 1820 settler: His letters, edited in consultation with Philipps' greatgranddaughter E.K. Heathcote. Pietermaritzburg: Shuter \& Shooter.

Kestell, Gertrude (Trudie) A. (1962) Gids tot die saal vir historiese kleredragte. Bloemfontein: National Museum.

Keuris, Marisa (2013) 'J.R.L. van Bruggen (Kleinjan) se eenbedryf "Bloedrivier” uit Bakens: Gedramatiseerde mylpale uit die Groot Trek (1938/1939) - 'n terugblik vanuit 2013: Geesteswetenskappe', Litnet Akademies: 'n Joernaal vir die Geesteswetenskappe 10.3: 629-650.

Khan, Farieda (1992) 'Hidden heritage: Our past, our future', Myths, monuments, museums: New premises? History Workshop, 16-18 July 1992, University of the Witwatersrand, Johannesburg, 1-15. http://wiredspace.wits. ac.za/handle/10539/7848

Kirchhoff, Ami and Werner Kirchhoff (2016) Peter Kirchhoff: Lebenskünster - artist of life. Johannesburg: privately published.

Kirsten, Marnell (2014) Alternative to what? The rise of Loslyf magazine. M Visual Studies thesis, University of Stellenbosch.

Kistner, Ulrike (2012) 'Vryheidspark and other governmonumentalities: Walking and working through Pretoria, government capital', Image \& Text 19: 6-13. 
Kleijn, Angie (2015) Voortrekkers, generaals en presidente was vrymesselaars. www.bronberger.co.za/ index.php?option=com_content $\&$ view=article \&id=3021:voortrekkers-generaals-en-presidente-wasvrymesselaars \&catid $=50$ :toeka-se-dae\&ltemid $=76$

Klein, Melanie C. (2008) Masculinity contested: Strategies of resistance in art from South Africa and the oeuvre of Wim Botha. PhD thesis, Hochschule für Grafik und Buchkunst Leipzig.

Klemm, Rosemarie and Dietrich Klemm (2008) Stones and quarries in ancient Egypt. London: British Museum Press.

Klopper, Ronell R. and Gideon F. Smith (2010) 'Asphodelaceae Alooideae: Reinstatement of Aloe spectabilis', Bothalia 40.1: 91-93.

Klopper, Sandra (1984) 'A man of splendid appearance, Angas's Utimuni, nephew of Caha late Zulu king', in Tribes and kingdoms, eds J.S. Bergh and A.P. Bergh. Cape Town: Don Nelson, 3-24.

Klopper, Sandra (1992) The art of Zulu-speakers in northern Natal-Zululand: An investigation of the history of beadwork, carving and dress from Shaka to Inkatha. PhD thesis, University of the Witwatersrand.

Kluppels, Anke (2009) 'The struggle to become South African': National identity and collective memory in South Africa: Reconciliation day. MA thesis, Erasmus University, Rotterdam. http://hdl.handle.net/2105/6402

Knight, Ian (1999) Great Zulu commanders. London: Arms and Armour.

Koopman, Adrian and John Deane (2005) 'New names for old: Transformation in the streets of Pietermaritzburg', Natalia: Journal of the Natal Society Foundation 35: 85-90.

Kotzé, D.J., ed. (1950) Letters of the American missionaries, 1835-1838. Cape Town: Van Riebeeck Society.

Krauss, Rosalind E. (1977) Passages in modern sculpture. London: Thames and Hudson.

Kriel, Mariana (2010) 'Culture and power: The rise of Afrikaner nationalism revisited', Nations and Nationalism 16.3: 402-422.

Krige, Eileen J. (1981) The social system of the Zulus. Pietermaritzburg: Shuter \& Shooter (first published 1936). Krischen, Fritz (1938) Die griechische Stadt: Wiederherstellungen. Berlin: Gebr. Mann.

Kruger, Cecilia (2002) Heritage resource management in South Africa: A case study of the Voortrekker Monument heritage site, Pretoria. MA thesis, University of Pretoria. https://repository.up.ac.za/handle/2263/25590

Kruger, Cecilia and Estelle Pretorius (2009) 'Alternative narrative of the Voortrekker Monument: The contribution of black labour to the construction of the Voortrekker Monument (1931-1949)', unpublished manuscript, Voortrekker Monument and National Heritage Site, Pretoria (HF Archives).

Kruger, Cecilia and Marie van Heerden (2005) 'The Voortrekker Monument heritage site: A new statement of significance', Historia: Journal of the Historical Association of South Africa 50.2: 237-260.

Kruger, J.J. (1968) 'Willem Hermanus Coetzer', in Our Art (Ons kuns) 1. Pretoria: Foundation for Education, Science and Technology, 97-101 (1st ed. 1959).

Kruger, Nellie (1972) Die Voortrekkertapisserie in die museum van die Voortrekkermonument/The Voortrekker tapestry in the museum of the Voortrekker Monument. Pretoria: Board of Control, Voortrekker Monument. Kruger, Nellie (1988) Die geskiedenis van die Voortrekker-muurtapisserie. Pretoria: Gutenberg Boekdrukkers. Krynauw, D.W. (1946) 'Uit die geskiedenis van Pietermaritzburg', Die Natalse Afrikaner 12 December.

Laband, John (1995) Rope of sand: The rise and fall of the Zulu kingdom. Johannesburg: Jonathan Ball (same edition as The rise \& fall of the Zulu nation. London: Arms and Armour, 1997).

Laband, John (2001) 'The military significance of the Battle of Blood River/Ncome', in Malefane (2001), 24-29.

Laband, John (2014) Zulu warriors: The battle for the South African frontier. New Haven and London: Yale University Press.

Laband, John (2017) The assassination of King Shaka. Cape Town and Johannesburg: Jonathan Ball.

Laband, John and Robert F. Haswell (1988) Pietermaritzburg, 1838-1988: A new portrait of an African city. Pietermaritzburg: University of Natal Press and Shuter \& Shooter.

Labuschagne, J. Andrë (1983) Pietermaritzburg and preservation: A cultural geographic interpretation, vols. 1-2. MA thesis, University of Natal, Pietermaritzburg.

Labuschagne, J. Andrë (1986) 'The oldest houses in Pietermaritzburg reconsidered', Natalia: Journal of the Natal Society Foundation 16: 51-78.

Labuschagne, J. Andrë (1988) 'The Church of the Vow', in Laband and Haswell (1988), 28.

Labuschagne, Pieter (2013a) 'A spatial analysis of the Ncome/Blood River monuments/museum complex as hermeneutic objects of reconciliation and nation building', South African Journal of Art History 28.3: 104-116.

Labuschagne, Pieter (2013b) 'Memorabilia and the formation of cultural identity: Afrikaner folk festivals, 1938 to 1952', South African Journal of Cultural History 27.1: 23-46.

Labuschagne, Pieter (2013c) 'The Afrikaner cattle breed as a foundational symbol in Afrikaner culture: The legacy of Rooi Joseph du Plessis', South African Journal of Cultural History 27.2: 36-54.

Labuschagne, Pieter (2014) 'The Women's Monument and memorial complexity in the context of political change: From memorial exclusivity to monument(al) inclusivity', South African Journal of Art History 29.2: 30-43.

Landau, Paul S. (2010) Popular politics in the history of South Africa, 1400-1948. New York: Cambridge University Press. 
Le Cordeur, B.A., ed. (1960) South African archival records, Natal no. II: Records of the Natal Executive Council, 1

(1846-1848). Cape Town: National Commercial Printers.

Lea, Henry (1936) A veld farmer's adventures, illustrated by the author. London: F. Muller.

Lee, R.W. (1946) An introduction to Roman Dutch law, 4th ed. Oxford: Clarendon Press.

Legassick, Martin and Robert Ross (2010) 'From slave economy to settler capitalism', in Hamilton, Mbenga and Ross (2010), 253-318.

Leverton, Basil (1988) 'The Natal Witness and “open testimony”', in Laband and Haswell (1988), 202-204.

Lewis, Bernard (1940) Child heroes of South Africa. Cape Town: Unie-Volkspers.

Leyds, Willem Johannes (1906) The first annexation of the Transvaal. London: T.F. Unwin.

Libert, Giancarlo (2009) L'emigrazione piemontese nel mondo: una storia millenaria. Chivasso: Aquattro.

Liebenberg, Barend J. (1977) Andries Pretorius in Natal. Pretoria and Cape Town: H\&R Academica.

Lima, Álvaro Luís (2012) 'Screw the nation! Queer nationalism and representations of power in contemporary South African art', African Arts 45.4: 46-57.

Lockhart, Bill, Beau Schriever, Bill Lindsey and Carol Serr (2016) 'Other J Marks', Society for Historical Archaeology: 35-36. https://sha.org/bottle/pdffiles/JOther.pdf

Lonsdale, F.M. (1981) 'The Battle of Congella', Military History Journal 5.3: not paginated. http://samilitaryhistory. org/vol053fl.html

Lowenthal, David (1994) 'Identity, heritage, history’, in Gillis (1994), 41-57.

Lugg, Harry C. (1949) Historic Natal and Zululand. Pietermaritzburg: Shuter \& Shooter.

Luiselli, Maria Michela (2011) 'The Ancient Egyptian scene of "Pharaoh smiting his enemies": An attempt to visualize cultural memory?' in Cultural memory and identity in ancient societies, ed. Martin Bommas. London and New York: Continuum, 10-25.

Lukehart, Peter M., ed. (1993) The artist's workshop. Washington: National Gallery of Art (distributed by the University Press of New England, Hanover and London).

Maderna, Caterina (2007) 'Aristodikos und “Kritios-Knabe”: Von der Bedeutung des Stils in der griechischen Plastik', in MOUSEION. Beiträge zur antiken Plastik: Festschrift zu Ehren von Peter Cornelis Bol, eds Hans von Steuben, Götz Lahusen and Haritini Kotsidu. Möhnesee: Bibliopolis, 173-185.

Magubane, Bernard M. (1996) The making of a racist state: British imperialism and the Union of South Africa, 1875-1910. Trenton, NJ: Africa World Press.

Malan, Jan H. (1918) Boer en barbaar of die geskiedenis van die Voortrekkers tussen die jare 1835-1840, en verder, 2nd ed. Bloemfontein: Nationale Pers (1st ed. 1911).

Malefane, K., ed. (2001) Arts and culture: The re-interpretation of the Battle of Blood River/Ncome (one-day seminar held on 31 October 1998, University of Zululand, KwaDlangezwa). Pretoria: Department of Arts, Culture, Science and Technology.

Mallgrave, Harry and Eleftherios Ikonomou (1994) Empathy, form, and space: Problems in German aesthetics, 1873-1893. Santa Monica, CA: Getty Center for the History of Art and the Humanities.

Marais, Vida (1947) 'n Jong Pretorianse beeldhouer: Hennie Potgieter', Voorslag January: 27.

Maré, Estelle A. (2002) 'The aesthetics of ideology: The vicissitude of monuments', Suid-Afrikaanse Tydskrif vir Kultuurgeskiedenis 16.2: 15-24.

Maré, Estelle A. (2004) 'A critique of monuments', Acta Academica 36.3: 73-97.

Maré, Estelle A. (2007) 'Monumental complexity: Searching for the meaning of a selection of South African monuments', South African Journal of Art History 22.2: 36-48.

Maré, Estelle A. (2009) 'The influence of the dominance of cultures on artefacts: Two case studies - Córdoba, Spain, and Blood River, South Africa', South African Journal of Art History 24.1: 121-136.

Mark, Robert and Ahmet Ş. Çakmak (1992) Hagia Sophia from the age of Justinian to the present. Cambridge: Cambridge University Press.

Marks, Shula and Stanley Trapido (1987) 'The politics of race, class and nationalism', in The politics of race, class and nationalism in twentieth-century South Africa, eds Shula Marks and Stanley Trapido. London: Longman, 1-70.

Marschall, Sabine (2001) 'The search for essence: “Africanness” in $20^{\text {th }}$ century South African architecture', South African Humanities 13: 139-154.

Marschall, Sabine (2004) 'The signifying power of the monumental image', Image and Text: A Journal of Design 11: 33-41.

Marschall, Sabine (2005) 'Forging national identity: Institutionalizing foundation myths through monuments', South African Journal of Cultural History 19.1: 18-35.

Marschall, Sabine (2010) Landscape of memory: Commemorative monuments, memorials and public statuary in post-apartheid South Africa. Leiden and Boston: Brill.

Marshall, Richard (2008) A social and cultural history of Grahamstown, 1812 to c. 1845. MA thesis, Rhodes University, Grahamstown. https://core.ac.uk/download/pdf/11984108.pdf 
Marx, Christoph (2008) Oxwagon sentinel, radical Afrikaner nationalism and the history of the 'Ossewabrandwag'. Berlin: Litt (English translation of Im Zeichen des Ochsenwagen: Der radikale Afrikaaner-Nationalismus in Südafrika und die Geschichte der Ossewabrandweg. Berlin: Litt, 1998).

Marx, Christoph (2016) 'Zukunft durch Apartheid? Verwoerds Rassenideologie, Südafrikas Außenpolitik und der Westen', Zeithistorische Forschungen/Studies in Contemporary History, 13.2: 210-230. https://zeithistorischeforschungen.de/2-2016/id\%3D5353?language=en

Mashatile, Paul (2012) 'Address by Minister Paul Mashatile on the occasion to commemorate the declaration of the Voortrekker Monument as a national heritage [sic]', 28 March 2012, Department of Arts and Culture. https:// www.sanews.gov.za/south-africa/voortrekker-monument-now-national-heritage-site.

Masina, Edward Muntu (2006) Zulu perceptions and reactions to the British occupation of land in Natal colony and Zululand, 1850-1887: A recapitulation based on surviving oral and written sources. PhD thesis, University of Zululand, KwaDlangezwa. http://uzspace.unizulu.ac.za:8080/xmlui/bitstream/handle/10530/425/ Zulu\%20perceptions\%20and\%20reactions\%20to\%20the\%20British\%20occupation\%20of\%20land.\%20 E.M.\%20Masina.pdf?sequence $=18$ isAllowed $=y$

McGill, Alexander (1977) 'Military use of animals in South Africa, 1400-1881', Scientia Militaria: South African Journal of Military Studies 7.4: 45-54.

McKearin, Helen and Kenneth M. Wilson (1978) American bottles and flasks and their ancestry. New York: Crown Publishers.

Meintjies, Johannes (1973) The Voortrekkers: The story of the Great Trek and the making of South Africa. London: Cassel.

Merrington, Peter (2001) 'A staggered Orientalism: The Cape-to-Cairo imaginary’, Poetics Today 22.2: 323-364.

Meskell, Lynn (2007) 'Living in the past: Historic futures in double times', in Murray, Shepherd and Hall (2007), 165-180.

Messimer, Douglas (2011) 'Where does the Masonic Lodge meet?' www.tuckahoelodge347.org/lodgeContent/ nuggets_2011/02\%20February\%20-\%20Where\%20Does\%20the\%20Lodge\%20Meet.pdf

Metcalf, Thomas (1980) 'Architecture and empire', History Today 30.12 (December): 7-12.

Meurant, Louis Henri (1885) Sixty years ago, or the reminiscences of the struggle for freedom of the press in South Africa and the establishment of the first newspaper in the Eastern Province. Cape Town: Saul Solomon \& Co.

Miller, Kim and Brenda Schmahmann, eds (2017) Public sculpture in South Africa: Bronze warriors and plastic presidents. Bloomington: Indiana University Press.

Minty, Zayd (2006) 'Post-apartheid public art in Cape Town: Symbolic reparations and public space', Urban Studies 43.2: 421-440.

Mitchell, Peter (2002) The archaeology of southern Africa. Cambridge: Cambridge University Press.

Mitchell, William J.T. (1986) Iconology: Image, text, ideology. Chicago and London: University of Chicago Press.

Mitchell, William J.T. (1990) 'The violence of public art: “Do the right thing”, Critical Inquiry 16.4: 880-899.

Mitthof, Fritz and Günther Schörner, eds (2017) Columna Traiani - Traianssäule: Siegesmonument und Kriegsbericht in Bildern. Beiträge der Tagung in Wien anlässlich des 1900. Jahrestages der Einweihung, 9. -12. Mai 2013.

Wien: Holzhausen. https://www.oapen.org/search?identifier $=630990$

Moerdijk, Gerard (1919) Kerkgeboue vir Suidafrika. Johannesburg: privately published.

Moerdijk, Gerard (1920) 'Die nasionale waarde van 'n gedenkteken', Die Banier February: 164-165.

Moerdyk, Gerard (1935) Die geskiedenis van boukuns. Pretoria: J.L. van Schaik.

Moerdyk, Gerard (1938) 'Die Voortrekker-Monument', Koers: Bulletin for Christian Scholarship 6.3: 1-4.

Molema, S.M. (1987) Chief Moroka: His life, his times, his country and his people. Pretoria: Acacia (1st ed. 1951, Cape Town: Methodist Publishing).

Moodie, Dunbar (1980) 'Review of Serfontein 1978', Journal of South African Studies 7.1: 127-129.

Moodie, Dunbar (1975) The rise of Afrikanerdom: Power, apartheid, and the Afrikaner civil religion. Berkeley: University of California Press.

Moodie, Duncan C.F. (1888) History of the battles and adventures of the British, the Boers and the Zulus in southern Africa. Cape Town: Murray \& St. Leger.

Moore Smith, George C., ed. (1902) The autobiography of Lieutenant-General Sir Harry Smith, baronet of Aliwal on the Sutlej, G.C.B., vol. 2. London: J. Murray.

Moreeng, Boitumelo and Chitja Twala (2014) 'Monuments as spaces for enhancing social justice and sustainable learning in history teaching: A case of the Voortrekker Monument', Mediterranean Journal of Social Sciences 5.7: 491-497.

Morton, David (2015) 'A Voortrekker memorial in revolutionary Maputo', Journal of Southern African Studies 41.2: 335-352.

Mostert, Dirk (1940) Gedenkboek van die ossewaens of die pad van Suid-Afrika: Eeufees: 1838-1939. Cape Town: Nasionale Pers.

Muller, Christoffel F.J. (1978) A pictorial history of the Great Trek: Visual documents illustrating the Great Trek. Cape Town: Tafelberg. 
Muller, Christoffel F.J. (1987) Die oorsprong van die Groot Trek. Pretoria: Unisa Press (1st ed. 1974).

Muller, Christoffel F.J., Floris A. van Jaarsveld, Theo van Wijk and Maurice Boucher, eds (1979) South African history and historians: A bibliography. Pretoria: University of South Africa.

Munro, Ion S. (1953) 'The British Academy of Arts in Rome', Journal of the Royal Society of Arts 102: 42-56.

Murray, Colin (1992) Black Mountain: Land, class and power in the eastern Orange Free State 1880s to 1980s. Johannesburg: Wits University Press.

Murray, Martin J. (2013) Commemorating and forgetting: Challenges for the new South Africa. Minneapolis: University of Minnesota Press.

Murray, Noëleen, Nick Shepherd and Martin Hall (2007) Desire lines: Space, memory and identity in the post-apartheid city. London: Routledge.

Muybridge, Eadweard (1887) Animal locomotion: An electro-photographic investigation of consecutive phases of animal movements, vol. 9: Horses. Philadelphia: University of Philadelphia.

Naidoo, Balasundram (1982) 'David Dale Buchanan as editor of the Natal Witness, 1846-56', in Archives year book of South African history, 40. Pretoria: Die Staatsdrukker.

Naidoo, Jay (1985) 'Was the Retief-Dingane treaty a fake?' History in Africa 12: 187-210.

Naidoo, Jay (1989) Tracking down historical myths: Eight South African cases. Johannesburg: AD Donker.

Nasson, Bill (2000) 'The South African War/Anglo-Boer War 1899-1902 and political memory in South Africa', in The politics of war memory and commemoration, eds Timothy G. Asplant, Graham Dawson and Michael Roper. Routledge Studies in Memory \& Narrative. London and New York: Routledge, 111-127.

Nasson, Bill and Albert Grundlingh, eds (2013) The war at home: Women and families in the Anglo-Boer War. Cape Town: Tafelberg.

Nathan, Manfred (1937) The Voortrekkers of South Africa: From the earliest times to the foundation of the republics. London: Gordon and Gotch.

Nathan, Manfred (1944) Not heaven itself: An autobiography. Durban: Knox.

Ncome/Blood River: Another point of view (2008). Ncome Museum and Monument Complex.

Ndlovu, Sifiso M. (1998) "“He did what any other person in his position would have done to fight the forces of invasion and disruption": Africans, the land and contending images of King Dingane ("the patriot") in the twentieth century, 1916-1950s', South African Historical Journal 38: 99-143.

Ndlovu, Sifiso M. (2009) 'Zulu nationalist literary representations of King Dingane', in Carton, Laband and Sithole (2009), 97-110.

Ndlovu, Sifiso M. (2017) African perspectives of King Dingane kaSenzangakhona: The second monarch of the Zulu kingdom. Berlin et al.: Springer International Publishing.

Nederduitsch Zuid-Afrikaansch Tijdschrift 16, 1839. https://catalog.hathitrust.org/Record/100432264

Nel, Louis J. and Ernest G. Jansen (1939) Uit die Voortrekkertyd: Herinneringe van Louis Jacobus Nel. Pretoria: J.L. van Schaik.

Newton Thompson (1946) 'The Hon. Mr. Justice C. Newton Thompson', South African Law Journal 63.1: 1-5 (no author).

Newton Thompson (1979) The Joyce Newton Thompson Collection was presented to the University of Cape Town Libraries in 1977 by Mrs Newton Thompson and numbers ca 4497 items, a list compiled by L.H. Twentyman Jones. Cape Town: UCT Libraries. https://atom.lib.uct.ac.za/index.php/joyce-newton-thompson-collection

Newton Thompson, Joyce (1966) 'William Rowland Thompson: Frontier merchant', Africana Notes and News 17.4 (December): 139-166.

Nienaber, Gabriel S. (1968) Louis Henri Meurant, 'n vroeë Afrikaanse joernalis. Cape Town: Nasionale Boekhandel.

Nienaber, Petrus J. (1950) Dr. O'Kulis met sy eselskakebeen, of, die lewe en werk van Ds. Willem Postma (1874-1920). Johannesburg: Voortrekkerpers.

Nieslony, Magdalena (2016) ‘Šklovskij, Hildebrand und die Suprematisten’, in Aurenhammer and Prange (2016), 275-288.

Nuttall, Sarah and Carli Coetzee, eds (1998) Negotiating the past: The making of memory in South Africa. Cape Town: Oxford University Press.

Nuzzi, Cristina, ed. (1980) Arnold Böcklin e la cultura artistica in Toscana: Hans von Marées, Adolf von Hildebrand, Max Klinger, Karl Stauffer-Bern, Albert Welti, exhibition Fiesole, Palazzina Mangani, 24 July to 30 September. Rome: De Luca.

Oberholster, J.J. (1972) The historical monuments of South Africa. Cape Town: Rembrandt van Rijn Foundation for Culture.

Oberholster, J.J. and James Walton (1963) Dingane's kraal, Mgungundlovu, prepared for the Historical Monuments Commission. Pretoria(?): Commission for the Preservation of Natural and Historical Monuments, Relics and Antiques.

O’Brien, Sheilagh I. (2013) 'The construction of a "bitter hedge": Narrative, nationalism, and the construction of Afrikaner identity in the Voortrekker Monument', Crossroads: An Interdisciplinary Journal for the Study of History, Philosophy, Religion and Classics 6.2: 29-38. 
Official Guide (1955) = The Voortrekker Monument Pretoria, Official Guide (1955). Pretoria: The Board of Control of the Voortrekker Monument (further editions 1957, 1960, 1963, 1966, 1969, 1970).

Official Programme (1949) = Voortrekker Monument Inauguration Committee: Official programme for the inauguration of the Voortrekker Monument, December 13 to 16, 1949. Johannesburg.

Ogilvie, Grania (1988) The dictionary of South African painters and sculptors, including Namibia. Johannesburg: Everard Read.

O’Kulis, Dr [pseudonym for Willem Postma] (1918) Die boervrouw, moeder van haar volk. Bloemfontein: Nasionale Pers.

Oliphant, Andries Walter, Pattabi G. Raman and Mongane W. Serote, eds (2014) Freedom Park: A place of emancipation and meaning. Pretoria: Freedom Park Publishers.

O'Meara, D. (1983) Volkskapitalisme: Class, capital and ideology in the development of Afrikaner nationalism, 1934-1948. Johannesburg: Ravan, and Cambridge: Cambridge University Press.

O’Meara, Emily (1995) Grahamstown reflected. Grahamstown: Trustees of the Albany Museum.

Opperman, Gerrit (2007) 'Healing the wounds of conflict', presented at 4th African Congress on Peace through Tourism, Kampala, Uganda, 20-25 May. http://www.iipt.org/africa2007/PDFs/GerritOpperman.pdf.

Østergaard, Jan Stubbe and Anne Marie Nielsen (2014) Transformations: Classical sculpture in colour. Copenhagen: Ny Carlsberg Glyptotek.

Otto, W. (1974) 'Grepe uit 'n kleurryke artillerietradsie', Scientia Militaria: South African Journal of Military Studies 4.4: 35-41.

Owen ed. Cory (1926) = Owen, Francis (1926) The diary of the rev. Francis Owen, MA: Missionary with Dingaan in 1837-38; together with extracts from the writings of the interpreters in Zulu, messrs. Hulley and Kirkman, ed. George E. Cory. Cape Town: Van Riebeeck Society.

Parker, Grant, ed. (2017) South Africa, Greece, Rome: Classical confrontations. Cambridge: Cambridge University Press.

Parkington, John E. and Mike Cronin (1979) 'The size and layout of Mgungundlovu', South African Archaeological Society Goodwin Series 4: 133-148.

Parsons, Neil (2017) 'The story of Corey and !Korana origins at the Cape', Bulletin of the National Library of South Africa 71: 3-16.

Parsons, Neil (2018) Black and white bioscope: Making movies in Africa 1899 to 1925. Bristol and Chicago: Intellect. Passeggia, Luisa (2011) Lo studio Lazzerini: viaggio a Carrara in tre secoli di storia. Pisa Ospedaletto: Pacini.

Paton, Alan (1980) Towards the mountain: An autobiography. New York: Charles Scribner.

Pauw, Samuel (2006) ‘Moerdijk se inspirasie vir die Voortrekkermonument: 'n bespiegeling', Gerard Moerdijkgedenklesing III, Voortrekkermonument, Pretoria, 2 March 2006 (unpublished).

Peffer, John (2005) 'Censorship and iconoclasm: Unsettling monuments', Res 48 (Autumn): 45-60.

Pfisterer, Ulrich (2002) Donatello und die Entdeckung der Stile, 1430-1445. München: Hirmer.

Pillman, Naka (1984) Laurika Postma: 'n biografie. Pretoria: De Jager-HAUM.

Poland, Marguerite, David Hammond-Tooke and Leigh Voigt (2003) The abundant herds: A celebration of the Nguni cattle of the Zulu people. Vlaeberg: Fernwood Press.

Pols, Ivor (1988) 'The Voortrekker Museum', in Laband and Haswell (1988), 163-164.

Pope-Hennessy, John Wyndham (1993) Donatello: Sculptor. New York: Abbeville Press.

Potgieter, Hendrik and N.H. Theunissen (1938) Kommandant-General Hendrik Potgieter, with drawings by Rene Shapshak. Johannesburg: Afrikaanse Pers.

Potgieter, Hennie (1948) 'Ons kunstenares Laurika Postma', Die Taalgenoot [8-9?] January.

Potgieter, Hennie (Hendrik Christoffel) (n.d.) 'Geskiedenis van die historiese fries van die Voortrekker Monument' (unpublished and undated manuscript, with an attachment of sketches and important information on the marble panels, HF Archives at the Voortrekker Monument 3548).

Potgieter, Hennie (1987) Voortrekker Monument, with photographs by Dotman Pretorius and Alan Yates. Pretoria: Hennie's Secretarial Services.

Preller, Retief (1917) = Preller, Gustav Schoeman (1917) Piet Retief: Lewensgeskiedenis van die grote Voortrekker. Pretoria: J.L. van Schaik.

Preller (1924) 'Die Retief-Dingaan Traktaat' in Cory, Preller and Blommaert (1924), 13-67.

Preller, Dingaansdag (1928) = Preller, Gustav Schoeman, ed. (1928) Hoe ons aan Dingaansdag kom: Jan Bantjes se dagverhaal van die winkommado. Bloemfontein: Nasionale Pers.

Preller, Sketse (1928) = Preller, Gustav Schoeman (1928) Sketse en opstelle. Pretoria: J.L. van Schaik.

Preller, Pretorius (1937) = Preller, Gustav Schoeman (1937) Andries Pretorius: Lewensbeskrywing van die Voortrekker kommandant-generaal. Johannesburg: The Afrikaans Press.

Preller, Day-dawn (1938) = Preller, Gustav Schoeman (1938) Day-dawn in South Africa. Pretoria: Wallachs.

Preller, Pretorius (1940) = Preller, Gustav Schoeman (1940) Andries Pretorius: Lewensbeskrywing van die Voortrekker kommandant-generaal, 2nd ed. Johannesburg: Afrikaanse Pers. 
Preller, Voortrekkermense 1 (1918) = Preller, Gustav Schoeman (1918) Voortrekkermense, vol. 1. Cape Town: Nasionale Pers.

Preller, Voortrekkermense 2 (1920) = Preller, Gustav Schoeman (1920) Voortrekkermense, vol. 2. Cape Town: Nasionale Pers.

Preller, Voortrekkermense 3 (1922) = Preller, Gustav Schoeman (1922) Voortrekkermense, vol. 3. Cape Town: Nasionale Pers.

Preller, Voortrekkermense 4 (1925) = Preller, Gustav Schoeman (1925) Voortrekkermense, vol. 4. Cape Town: Nasionale Pers.

Preller, Voortrekkermense 5 (1938) = Preller, Gustav Schoeman (1938) Voortrekkermense, vol. 5. Cape Town: Nasionale Pers.

Preller, Voortrekkermense 6 (1938) = Preller, Gustav Schoeman (1938) Voortrekkermense, vol. 6. Cape Town: Nasionale Pers.

Pretorius, Celestine J. (1988) 'Africana-prente uit die tyd van die Groot Trek', in Herdenkingsjaar 1988: Portugese, Hugenote en Voortrekkers, ed. J.S. Bergh. Pretoria: De Jager-Haum, 151-176.

Pretorius, Estelle (2003) 'The Italians and the Voortrekker Monument', paper presented to the Northern Transvaal GSSA branch, 18 August 2003. www.eggsa.org/articles/italians_and_voortrekker_monument_e.htm

Pretorius, Quarta (2011) Vegkop 175 jaar: Geskiedeneis van Vegkop 1836-2011. Heilbron: Heilbron Herald.

Prinsloo, P.J.J. (1987) E.G. Jansen se rol in belang van die Afrikaner in Natal. PhD thesis, North-West University, Potchefstroom. https://dspace.nwu.ac.za/handle/10394/16212

Prinsloo, P.J.J. (1995) 'Die rol van die Saamwerk-Unie in die beslaggewing van Afrikaanse taaleksamens in Natal, 1917-1928', Literator 16.2: 225-245.

Prinsloo, P.J.J. (1996) 'Die oorsprong van die ideaal om 'n monument ter ere van die Voortrekkers op terig', Historia: Journal of the Historical Association of South Africa 41.1: 62-73.

Prinsloo, Willem-Jan (1971) 'Aan die Ossewa-monument by Bloedrivier is 'n lang geskiedenis verbonde - 'n geskiedenis wat oor'n tydperk van meer as 'n eeu trek', Huisgenoot (17 December): 66-71.

Raath, A.W.G. (2001) 'Die teologiese agtergronde van die Voortrekkergelofte (1838)', Hervormde Teologiese Studies 57.3/4: 908-958.

Rankin, Elizabeth (1989) Images of wood: Aspects of the history of sculpture in $20^{\text {th }}$ century South Africa. Johannesburg: Johannesburg Art Gallery.

Rankin, Elizabeth (1991) 'Training and trading: The influence of tuition and the art market on some South African sculptors', de arte 43 (April): 5-25.

Rankin, Elizabeth (2013) 'Creating/curating cultural capital: Monuments and museums for post-apartheid South Africa', Humanities 2.1: 72-98. www.mdpi.com/journal/humanities

Rankin, Elizabeth (2017) 'A Janus-like juncture: Reconciling past and present at the Voortrekker Monument and Freedom Park', in Miller and Schmahmann (2017), 3-28.

Rankin, Elizabeth and Rolf M. Schneider (2017) ““Copy nothing”: Classical ideals and Afrikaner ideologies at the Voortrekker Monument', in Parker (2017), 141-212.

Ransford, Oliver (1972) The Great Trek. London: Murray.

Raper, Peter E., Lucie A. Möller and L. Theodorus du Plessis (2014) Dictionary of South African place names, 4th ed. Johannesburg and Cape Town: Jonathan Ball.

Rasmussen, R. Kent (1978) Migrant kingdom: Mzilikazi's Ndebele in South Africa. London: Rex Collings, and Cape Town: David Philip.

Reitz, Francis W. (1918) 'Die gedenkstene van die traktaat tussen Andries Pretorius en Panda', Die Huisgenoot 3.25 (May): 372.

Retief, Petrus J. (1988) Die Retief-familie in Suid-Afrika: 1688-1988. Pretoria: Dr P.J. Retief.

Review of report on Freemasonry (1942) = A review of the Report of the Synodical Commission of the Dutch Reformed Church (Cape) on Freemasonry (1942). Cape Town: publisher not identified.

Reynolds, Rex and Barbara Reynolds (1974) Grahamstown from cottage to village. Cape Town: David Philip.

Rodekamp, Volker, ed. (2009) Völkerschlachtdenkmal, 3rd ed. Leipzig: Stadtgeschichtliches Museum.

Romanelli, Romano (1954) Romano Romanelli: Catalogo opere e cenni biografici. Florence: Vallecchi.

Rosenthal, Eric (1960) Heinrich Egersdörfer: An old-time sketch book - 'n Outydse sketsboek. Cape Town: Nasionale Boekhandel.

Ross, Marc Howard (2007) Cultural contestations in ethnic conflict. Cambridge: Cambridge University Press.

Ross, Robert, Anne Melk Mager and Bill Nasson, eds (2011) The Cambridge history of South Africa, vol. 2. Cambridge: Cambridge University Press.

Roux, Naomi (2017) 'Mandela's walk and Biko's ghosts: Public art and the politics of memory in Port Elizabeth's city center', in Miller and Schmahmann (2017), 95-117.

Rubin, Martin (1983), 'Review of Paton 1980', African Literatures, Special Issue on Modern African Fiction 14.2: 261-266. 
Rufer, Mario (2007) 'Monuments, museums and the re-articulation of nation: Pedagogies, performances and subaltern apprehensions of memory', Intercultural Communication Studies 16.2: 158-177.

Russell, Ben and Will Wootton (2015) 'Presenting and interpreting the process of stone carving: The Art of Making in Antiquity project', in Interdisciplinary studies on ancient stone: ASMOSIAX, eds Patrizio Pensabene and Eleonora Gasparini. Rome: L'Erma di Bretschneider, 851-860.

Russell, Ben and Will Wootton (2017) 'Makers and making: Classical art in action', in The diversity of classical archaeology, eds Achim Lichtenberger and Rubina Raja. Turnhout: Brepols, 253-270.

Russell, Robert (1903) Natal: The land and its story, 9th ed. Maritzburg: P. Davis \& Sons.

Rycroft, David K. and A. Bhekabantu Ngcobo, eds (1988) The praises of Dingana. Pietermaritzburg: University of Natal.

Sani, G. (1992) History of the Italians in South Africa, 1489-1989. Johannesburg: Isando.

Saunders, Christopher (1988) The making of the South African past: Major historians on race and class. Cape Town: David Philip.

Saunders, Christopher and Nicholas Southey (2001) A dictionary of South African history. Cape Town: David Philip.

Savage, Kirk (1997) Standing soldiers, kneeling slaves: Race, war, and monument in nineteenth-century America. Princeton, NJ: Princeton University Press.

Scheepers, Johannes Jacobus (1983) Die geskiedenis van die Dundee-monument. Halfweghuis: Promedia.

Schmidt, Evamaria (1982) Geschichte der Karyatide: Funktion und Bedeutung der menschlichen Träger- und Stützfigur in der Baukunst. Würzburg: Triltsch.

Schmitz, Bruno (1900) Drei Kaiserdenkmäler: Ausgeführte Architekturwerke, vols 1-3. Berlin: Wasmuth.

Schneider, Rolf M. (1986) Bunte Barbaren: Orientalenstatuen aus farbigem Marmor in der römischen Repräsentationskunst. Worms: Wernersche Verlagsgesellschaft.

Schneider, Rolf M. (2008) 'Image and empire: The shaping of Augustan Rome,' in Conceiving the Empire: China and Rome compared, eds Fritz-Heiner Mutschler and Achim Mittag. Oxford: Oxford University Press, 269-298.

Schneider, Rolf M. (2010) 'Korai und Kouroi: Neue Menschenbilder aus Marmor im Mittelmeerraum', in Die griechische Welt. Erinnerungsorte der Antike, eds Elke Stein-Hölkeskamp and Karl-Joachim Hölkeskamp. Munich: C.H. Beck, 221-243.

Schneider, Rolf M. (2012) 'The making of Oriental Rome: Shaping the Trojan legend', in Universal empire: A comparative approach to imperial culture and representation in Eurasian history, eds Peter Fibiger Bang and Dariusz Kolodziejczyk. Cambridge: Cambridge University Press, 76-129.

Schoeman, Karel, ed. (1992) The British presence in the Transorange 1845-1854. Cape Town: Human \& Rousseau.

Schoeman, Karel (2003) Die wêreld van Susanna Smit, 1799-1863. Pretoria: Protea Boek Huis (1st ed. 1995, Cape Town: Human \& Rousseau).

Schönfeldt-Aultman, Scott M. (2006) 'Monument(al) meaning-making: The Ncome monument \& its representation of Zulu identity', Journal of African Cultural Studies 18.2: 215-234.

Schoonraad, Murray (1988) 'Suid-Afrikaanse kunstenaars se siening van die Groot Trek', Lantern: Tydskrif vir Kennis en Kultur 37.4: 75-82.

Schubert, Dietrich (1995) “'Frühlingslied”? Das Heinrich-Heine-Denkmal von Georg Kolbe in Frankfurt/Main', Heine Jahrbuch 34: 119-145.

Schulte, Birgit and Erich Ranfft, eds (1998) Die Bildhauerin Milly Steger 1881-1948: Die Grenzen des Frauseins aufheben. Hagen: Neuer Folkwang Verlag im Karl Ernst Osthaus-Museum.

Schwenke, Astrid (2009) 'Die historiese marmerfries in die Voortrekkermonument', Plus 50 4/5 (October/ November): $16-17$.

Schwenke, Astrid and Jackie Grobler (2013) ‘Die historiese marmerfries in die Voortrekkermonument, Pretoria: 'n bronne-evaluasie aan die hand van geselekteerde aspekte', S.A. Tydskrift van Kultuurgeskiedenis 27.1 (June): 114-138.

Scigliano, Eric (2005) Michelangelo's mountain: The quest for perfection in the marble quarries of Carrara. New York and London: Free Press.

Sellick, W.S.J. (1904) Uitenhage: Past and present, souvenir of the centenary 1804-1904. Uitenhage: Uitenhage Times.

Serfontein, Jan H.P. (1978) Brotherhood of power: An exposé of the secret Afrikaner Broederbond. Bloomington and London: Indiana University Press.

Settis, Salvatore, Anna Anguissola and Davide Gasparotto, eds (2015) Serial/portable classic: The Greek canon and its mutations. Milan: Fondazione Prada.

Shaman, Sanford S. (2005) 'The heights of contradictions', Art South Africa 3.4: 50-54.

Silke, Robert (2005) 'Mutual heights', Architect and Builder February/March: 42-49.

Sithole, Jabulani (2009) 'Changing meanings of the Battle of Ncome and images of King Dingane in twentieth century South Africa', in Carton, Laband and Sithole (2009), 322-330.

Smail, J.L. (1968) Monuments and trails of the Voortrekkers. Cape Town: Howard Timmins. 
Smit ed. Scholtz (1988) = Scholtz, Merwe (1988) Joernaal van 'n trek uit die dagboek van Erasmus Smit. Geredigeer deur Gustav S. Preller, ingelei en versorg deur Merwe Scholtz. Cape Town: Tafelberg.

Smit trans. Mears (1972) = Smit, Erasmus (1972) The diary of Erasmus Smit (Uit het dagboek van Erasmus Smit, ed. H.F. Schoon, 1897), trans. W.G.A. Mears. Cape Town: C. Struik.

Smith, Laurajane (2006) The uses of heritage. London and New York: Routledge.

Smith, Nico (2009) Die Afrikaner Broederbond: Belewinge van die binnekant. Pretoria: LAPA Uitgewers.

Smith, R.R.R. (1996) 'Typology and diversity in the portraits of Augustus', in Journal of Roman Archaeology 9: 30-47. Southey, Nicholas (1992) 'Andrew Harington', Kleio 24.1: 12-18.

Steenkamp, Alta (2006) 'Apartheid to democracy: Representation and politics in the Voortrekker Monument and Red Location Museum', Architectural Research Quarterly 10.3/4: 249-254.

Steenkamp, Alta (2008) 'Architecture rethought in relation to space, power and the body: A concise critical history of the Voortrekker Monument', Journal of the South African Institute of Architects (November/December): 60-68.

Steenkamp, Alta (2009) 'A shared spatial symbolism: The Voortrekker Monument, the Völkerslachtdenkmal [sic] and Freemasonry,' South African Journal of Art History 24.1: 150-160.

Steenkamp, Alta (2011) 'Ambiguous associations: Monuments referred to in the design of the Voortrekker Monument', South African Journal of Art History 26.3: 79-89.

Steenkamp, Alta (2015) 'The place of women in the Voortrekker Monument', South African Journal of Art History 30.1: 33-46.

Steenkamp, Anna Elizabeth (1876) 'Record of journal of our migration from our mother country to Port Natal', Cape Monthly Magazine September (reprinted in Bird, Annals 1 [1888], 459-468, and Collins [1990], 182-188).

Steenkamp, Anna Elizabeth (1939) Die dagboek van Anna Steenkamp en fragmentjies oor die Groot-Trek, verwerk deur A.G. du Toit en Dr Louis Steenkamp. Pietermaritzburg: Natalse Pers.

Stewart, Andrew (1996) Art, desire, and the body in Ancient Greece. Cambridge: Cambridge University Press.

Stewart, Andrew (2004) Attalos, Athens and the Akropolis: The Pergamene 'Little Barbarians' and their Roman and Renaissance legacy, with an essay on the Pedestals and the Akropolis south wall by Manolis Korres. Cambridge: Cambridge University Press.

Stewart, Andrew (2014) Art in the Hellenistic world: An introduction. Cambridge and New York: Cambridge University Press.

Steynberg, Coert (1982) Coert Steynberg: 'n Outobiografie. Roodepoort: CUM Boeke.

Steytler, F.A. (1958) 'n Voortrekkermonument te Pretoria, voorstel van pres. Kruger op 16 Desember 1888', Historia: Journal of the Historical Association of South Africa 3.1: 3-7.

Stilwell, Sean A. (2014) Slavery and slaving in African history. New York and Cambridge: Cambridge University Press.

Storm, J. (1989) 'Die konvensie van Sandrivier as die afsluiting van die Groot Trek', Hervormde Teologiese Studies 45.3: 680-695.

Strauss, H.W. (n.d.) Die historiese fries - 'n Waardering. BA essay, University of Pretoria.

Streak, Michael (1974) The Afrikaner as viewed by the English, 1795-1854. Cape Town: C. Struik.

Stuart, James (1854) De Hollandsche Afrikanen en hunne republiek in Zuid-Afrika. Amsterdam: G.W. Tielkemeijer.

Swanepoel, Nicolene (2007) Representations of cattle as cultural markers: Towards South African identities. M Tech Fine Art thesis, University of Johannesburg.

Swart, M.J., ed. (1989) Afrikanerbakens, Federasie van Afrikaanse Kultuurvereeniginge. Goodwood: Nasionale Boekdrukkery.

Swart, Sandra S. (2007) “"Motherhood and otherhood”: Gendered citizenship and Afrikaner women in the South African 1914 rebellion', African Historical Review 39.2: 41-57.

Swart, Sandra and Lize-Marié van der Watt (2008) “"Taaltriomf of taalverdriet?” An aspect of the roles of Eugène Marais and Gustav Preller in the Second Language Movement, circa 1905-1927', Historia: Journal of the Historical Association of South Africa 53.2: 126-150.

Te Water, Charles T. (1934) ‘An Academy of South African Art: Mr. Te Water’s scheme for a biennial exhibition', South Africa (1 June): 263.

Templin, J. Alton (1999) 'The ideology of a chosen people: Afrikaner nationalism and the Ossewa Trek, 1938', Nations and Nationalism 5.3: 397-417.

Theal, George McCall (1893) History of South Africa, from the foundation of the European settlement to our times, 1834-1854, vol. 2. London: Swan Sonnenschein.

Theal, George McCall (1902) The beginning of South African history. London: T.F. Unwin.

Theal, George McCall (1916) History of South Africa, from 1795-1872, vol. 3 (3rd ed.). London: G. Allan \& Unwin.

Theal, George McCall (1973) History of the Boers in South Africa, or the wanderings and wars of the emigrant farmers from their leaving the Cape Colony to the acknowledgment of their independence by Great Britain. Cape Town: S. Struik (first published in 1887, London: Swan Sonnenschein, Lowrey \& Co.).

Thom, Hendrik B. (1947) Die lewe van Gerrit Maritz. Cape Town: Nasionale Pers.

Thom, Hendrik B. (1949) Die Geloftekerk en ander studies oor die Groot Trek. Cape Town: Nasionale Pers. 
Thompson, Leonard (1976) Survival in two worlds: Moshoeshoe of Lesotho, 1786-1870. Oxford: Oxford University Press.

Thompson, Leonard (1985) The political mythology of apartheid. New Haven and London: Yale University Press. Thompson, Leonard (1995) A history of South Africa. New Haven: Yale University Press.

Toerien, H. (1975) 'Willem Hermanus Coetzer word 75', Lantern: A Journal of Knowledge and Culture 25.1: 24-36. Tomaselli, Keyan G. (1985) 'Popular memory and the Voortrekker films', Critical Arts: South-North Cultural and Media Studies 3.3: 15-24.

Trauseld, W.R. (1969) Wild flowers of the Natal Drakensberg. Cape Town, Johannesburg and London: Purnell.

Trichardt ed. Preller (1938) = Trichardt, Louis (1938) Dagboek van Louis Trichardt (1836-1838), ed. Gustav Schoeman Preller. Cape Town: Nasionale Pers.

Tully, H.C. (1932) 'The Voortrekker Memorial Hall', South African Architectural Record: 6-7. http:// wiredspace.wits.ac.za/bitstream/handle/10539/18872/Journal\%20of\%20SAAl-January-1932-001-jpeg. pdf? sequence $=1$ \&isAllowed $=\mathrm{y}$

Tweed, Hugh (2013) Dashing dragoon, anguished emissary: The story of William Samuel Hogge in southern Africa (1843-1852). Matador: Kibworth Beauchamp.

Tylden, G. (1938) 'The Cape Mounted Rifleman, 1827-1870', Journal of the Society for Army Historical Research 17.68: 227-231. http://www.jstor.org/stable/44226226

Uys, Ian S. (1976) ‘A Boer family’, Military History Journal 3.6: without page numbers. http://samilitaryhistory.org/ vol036iu.html

Uys, Ian S. (1988) 'Her Majesty’s loyal and devoted trekker leader: Petrus Lafras Uys', Natalia: Journal of the Natal Society Foundation 18: 30-40.

Van den Berg, Dirk (1995) 'Sculpture, power and iconoclasm: The Verwoerd statue', in Mechanisms of power, eds Rory Doepel and Andreas Bertold, 13-18 (conference proceedings of eleventh annual conference of the South African Association of Art Historians, University of the Witwatersrand, Johannesburg, July 1995).

Van der Merwe, Jan J.P. (2013) 'Vrymesselary voor die aanvang van die Suid-Afrikaanse Oorlog'. www.litnet.co.za/ vrymesselary-voor-die-aanvang-van-die-suid-afrikaanse-oorlog/

Van der Merwe, Pieter J. (1986) Die Matebeles en die Voortrekkers. Pretoria: Staatsdrukker.

Van der Merwe, Pieter L. (2008) 'SA-genealogie', Argiewe 5 (June). www.sagenealogie.com/archives/2008/ jun2008.pdf

Van der Merwe, Schalk D. (2017) On record: Popular Afrikaans music \& society, 1900-2017. Stellenbosch: Sun Press.

Van der Riet, Frank (1974) Grahamstown in early photographs. Cape Town: David Philip.

Van der Walt, Andries J.H. (1938) 'Hloma Amabutho', Huisgenoot: Gedenkuitgawe gewy aan die Groot Trek (December): 102-107.

Van der Walt, Gert (1974) 'Die onbekende voortrekker’, in Die Huisgenoot: spesiale gedenkalbum by geleentheid van die 25-jarige herdenkingsfees van die Voortrekkermonument (December): 80-82.

Van der Walt, Johannes C. (2009) Zululand true stories: 1780-1978. Richards Bay: Dr. J.C. van der Walt.

Van der Watt, Liese (1996) Art, gender, ideology and Afrikaner nationalism: A history of the Voortrekker Monument tapestries. MA thesis, University of Cape Town. https://open.uct.ac.za/handle/11427/18377

Van der Watt, Liese (1997) “'Savagery and civilisation”: Race as a signifier of difference in Afrikaner nationalist art', de arte 55 (April): 36-47.

Van der Watt, Liese (1998) 'The comradely ideal and the volksmoeder ideal: Uncovering gender ideology in the Voortrekker tapestry', South African Historical Journal 39.1: 91-110.

Van der Watt, Liese (2004) 'Identity's lack, identity's excess: Two works by Berni Searle and Minnette Vári’, in $A$ decade of democracy: South African art 1994-2004 - From the permanent collection of Iziko: South African National Gallery, ed. Emma Bedford. Cape Town: Double Storey Books and Iziko Museums of Cape Town, 120-127.

Van der Watt, Liese (2005) 'Art, gender ideology and Afrikaner nationalism: A case study', in Between union and liberation: Women artists in South Africa 1910-1994, eds Marion Arnold and Brenda Schmahmann. Aldershot and Burlington: Ashgate, 94-110.

Van der Westhuysen, Peter Jacobus (1994) Hennie Potgieter: Volkskunstenaar. MA thesis, University of Pretoria. http://upetd.up.ac.za/thesis/available/etd-12072011-081616/

Van Jaarsveld, Floris A. (1951) Die eenheidstrewe van die republikeinse Afrikaners. 1 Pioniershartstogte (1836-1864). Amsterdam: Swets \& Zeitlinger.

Van Jaarsveld, Floris A. (1961) The awakening of Afrikaner nationalism, 1868-1881. Cape Town: Human \& Rousseau.

Van Jaarsveld, Floris A. (1975) From Van Riebeeck to Vorster, 1652-1974: An introduction to the history of the Republic of South Africa. Johannesburg: Perskor.

Van Jaarsveld, Floris A. (1988) 'n Afrikanerperspektief op die Groot Trek: Simbool en ritueel', Historia: Historical Association of South Africa 33: 11-26.

Van Niekerk, Ada (1955) ‘The man who made the Monument', The Outspan (3 April). 
Van Niekerk, L.E. (2004) 'Leyds, Willem Johannes (1859-1940)', in Oxford dictionary of national biography. Oxford: Oxford University Press. https://doi.org/10.1093/ref:odnb/53749

Van Rensburg, Jeanette (2012) Die Boerevrou 1919-1931: 'n Kultuurhistoriese studie oor die eerste Afrikaanse vrouetydskrif. PhD thesis, University of Pretoria. http://repository.up.ac.za/bitstre.am/handle/2263/24176/ Complete.pdf?sequence $=10$

Van Robbroeck, Lize (2011) 'The Voortrekker in search of new horizons', in Grundlingh and Huigen (2011), unpaginated. http://rozenbergquarterly.com/reshaping-remembrance-the-voortrekker-in-search-of-newhorizons/

Van Robbroeck, Lize and Menán van Heerden (2017) 'Historical monuments: An interview with Lize van Robbroeck', LitNet Akademies. http://www.litnet.co.za/historical-monuments-interview-lize-van-robbroeck/

Van Rooyen, G.H. (1938) Kultuurskaate uit die Voortrekker-tydperk ('n Kultuur-historiese studie), 1. Bloemfontein, Cape Town and Port Elizabeth: Nasionale Pers.

Van Rooyen, G.H. (1940) Kultuurskaate uit die Voortrekker-tydperk ('n Kultuur-historiese studie), 2. Bloemfontein, Cape Town and Port Elizabeth: Nasionale Pers.

Van Vollenhoven, Anton (2017) 'Die veranderende betekenis van die Voortrekkermonument: Erfeniswins of erfenisverlies?' LitNet Akademies 14 (2). http://www.litnet.co.za/die-veranderende-betekenis-van-die-voortrekkermonument-erfeniswins-erfenisverlies/

Van Warmelo, Nicolaas J. (1938) History of Matiwane and the Amangwane tribe as told by Msebenzi to his kinsman Albert Hlongwane. Pretoria: Government Printer.

Van Zyl, Johan (2013) ‘The Women's Monument: Planning, design and inauguration', in Nasson and Grundlingh (2013), 210-225.

Van Zyl, M.C. (1986) ‘Die slag van Vegkop’, Historia: Journal of the Historical Association of South Africa 31: 63-70.

Venter, C. (1985) The Great Trek. Cape Town: Don Nelson.

Venter, C. (1991) 'Die Voortekker en die ingeboekte slawe wat die Groot Trek meegemaak het, 1835-1838', Historia: Journal of the Historical Association of South Africa 36: 14-29.

Verhoef, Grietjie (2008) 'Nationalism, social capital and economic empowerment: SANLAM and the economic upliftment of the Afrikaner people, 1918-1960', Business History 50.6: 695-713.

Vermeulen, Irma (1999) Man en monument: Die lewe en werk van Gerard Moerdijk. Pretoria: J.L. van Schaik.

Verwey, Cornel and Michael Quayle (2012) 'Whiteness, racism, and Afrikaner identity in post-apartheid South Africa', African Affairs 111.445: 551-575.

Vickers, Michael (2014) 'The caryatids on the Erechtheum at Athens: Questions of chronology and symbolism', Miscellanea Anthropologica et Sociologica 15.3: 119-133.

Vincent, Louise (2000) 'Bread and honour: White working class women and Afrikaner nationalism in the 1930s', Journal of Southern African Studies 26.1: 61-78.

Visagie, Jan C. (1996) 'Die fyn onderskeid tussen Voortrekkers en Trekboere’, Historia: Journal of the Historical Association of South Africa 41.2: 1-10.

Visagie, Jan C. (2005) 'Etherington oor die Afrikaner en die Groot Trek', Historia: Journal of the Historical Association of South Africa 50.1: 1-21.

Visagie, Jan C. (2011) Voortrekkerstamouers 1835-1845, 2nd ed. Pretoria: Protea Boekhuis.

Visagie, Jan C. (2014) Voortrekkerleiers en trekroetes. Pretoria: Die Erfenesstigting.

Visser, J.A. (2012) 'Die Suid-Afrikaanse jeug in Voortrekkertydperk', Scientia Militaria: South African Journal of Military Studies 15: 6-10.

Voigt, Johan C. (1899) Fifty years of the history of the Republic in South Africa (1795-1845), vol. 2. London: T. Fisher Unwin.

Voortrekker argiefstukke (1937) = Pretorius, H.S., Danïel W. Kruger and Coenraad Beyers, eds (1937) Voortrekkerargiefstukke, 1829-1849: Afgeskryf, toegelig, persklaar gemaak en van bladwysers voorsien. Pretoria: Staatsdrukker.

Voortrekker Memorial Church (1962) = The Voortrekker Memorial Church, Pietermaritzburg: National monument: Symbol of our faith in the future (1962). Pietermaritzburg: Dutch Reformed Church of Natal.

Voortrekker Museum Pietermaritzburg (1912) Voortrekkers Museum: Catalogue - Katalogus. Pietermaritzburg.

Voortrekkermuseum Pietermaritzburg (1982) Voortrekkermuseum, Pietermaritzburg. Pietermaritzburg: Raad/Board.

Vusumuzi Shongwe, Acquirance (2004) King Dingane: A treacherous tyrant or an African nationalist? PhD thesis, University of Zululand, KwaDlangezwa. http://uzspace.uzulu.ac.za/bitstream/handle/10530/1123/ King\%20Dingaan\%20-\%20A.V.\%20Shongwe.pdf?sequence=1\%20vusumuzi\%20shongwe\%20dingane

Wacquant, Loïc (2014) 'Putting habitus in its place: Rejoinder to the symposium', Body \& Society 20.2: 118-139.

Walker, Eric Anderson (1934) The Great Trek. London: A. and C. Black.

Wallinga, Tammo (2010) 'Johannes van der Linden and his draft code for Holland', Fundamina: A Journal of Legal History 16.1: 563-577.

Ward, Val (2007) 'My first African excursion [diary by Marianne Faure]', Natalia: Journal of the Natal Society Foundation 36-37: 1-20. http://www.natalia.org.za/Files/36-37/Natalia\%2036-37\%20pp1-20\%20C.pdf 
Weilbach, Johann D. and C.N.J. du Plessis (1882) Geschiedenis van de emigranten-boeren en van den Vrijheidsoorlog. Kaapstad: Saul Solomon.

Welsh, Frank (1998) A history of South Africa. London: Harper Collins.

Wessels, Johannes Wilhelmus (1908) History of the Roman-Dutch law. Grahamstown: African Book Company. Whitaker, R. (1997) 'The classics in South African society: Past, present and future', Acta Classica 40: 5-14. Wienand, Annabelle (2012) ‘Portraits, publics and politics: Gisele Wulfsohn’s photographs of HIV/ AIDS, 1987-2007’, Kronos 38.1 (January). http://www.scielo.org.za/scielo.php?script=sci_arttex $\mathrm{t} \& \mathrm{pid}=\mathrm{S} 0259-01902012000100009$

Wilcox, Mark F. (1962) Proud endeavorer: The story of a Yankee on a mission to South Africa. New York: Graphic Press.

Wildenboer, Liezl (2015) 'The thirty-three articles and the application of law in the Zuid-Afrikaansche Republiek', Fundaminia: A Journal of Legal History 21.2: 457-476.

Wilkerson, Isabell (1994) 'Apartheid is demolished. Must its monuments be?' New York Times 25 September. www.nytimes.com/1994/09/25/world/apartheid-is-demolished-must-its-monuments-be. html?pagewanted $=2 \& \mathrm{src}=\mathrm{pm}$

Wilkins, Ivor and Hans Strydom (1978) The super Afrikaners: Inside the Afrikaner Broederbond. Johannesburg: Jonathan Ball.

Wilson, Monica and Leonard Thompson, eds (1969) The Oxford history of South Africa. New York: Oxford University Press.

Wittman, Laura (2011) The Tomb of the Unknown Soldier, modern mourning, and the reinvention of the mystical body. Toronto Italian Studies. Toronto: University of Toronto Press.

Witz, Leslie (2003) Apartheid's festival: Contesting South Africa's national past. Bloomington and Indianapolis: Indianapolis University Press.

Witz, Leslie, Gary Minkley and Ciraj Rassool (2017) Unsettled history: Making South African public pasts. Ann Arbor: University of Michigan Press.

Wölfflin, Heinrich (1929) Principles of art history: The problem of development of style in later art, 7th ed., trans. Mary D. Hottinger. New York: Dover Publications.

Wölfflin, Heinrich (1946) 'Ein Künstler über Kunst’, in Heinrich Wölfflin: Kleine Schriften (1886-1933), ed. Joseph Gantner. Basel: Schwabe, 84-88.

Wood, Marilee (1996) 'Zulu beadwork', in Zulu treasures (1996), 143-170.

Woods, Denise (2006) South Africa reaping the whirlwind of national idolatry. Cape Town: Struik. Worden, Nigel (2000) The making of modern South Africa, 3rd ed. Oxford: Blackwell.

Wright, John (1996) 'Making the John Stuart Archive', History in Africa 23: 333-350.

Wright, John (2009) 'Revisiting the stereotype of Shaka's “devastastions”', in Carton, Laband and Sithole (2009), 69-81.

Wylie, Dan (2009) 'White myths of Shaka', in Carton, Laband and Sithole (2009), 82-86.

Zanker, Paul, Björn C. Ewald and Julia Slater (2012) Living with myths: The imagery of Roman sarcophagi. Oxford: Oxford University Press.

Zitko, Hans (2016) 'Probleme der Form: Bemerkungen zu Konrad Fiedler, Adolf von Hildebrand, Ernst Cassirer und Georg Simmel', in Aurenhammer and Prange (2016), 29-42.

'Zuid-afrikaansche kronyk. September-October, 1838', Nederduitsch Zuid-Afrikaansch Tijdschrift 15: 472-476. https://catalog.hathitrust.org/Record/100432264

'Zuid-afrikaansche kronyk. January-February, 1839', Nederduitsch Zuid-Afrikaansch Tijdschrift 16: 152-160. https:// catalog.hathitrust.org/Record/100432264

Zulu treasures (1996) = Zulu treasures: Of kings \& commoners: A celebration of the material culture of Zulu people (Amagugu kaZulu: Amakhosi Nabantukazana: umgubho wezinto ezihambisana namasiko amaZulu), Ulundi, KwaZulu Cultural Museum. Durban: Local History Museums (2nd ed. 2011). 